$4-2021$

\title{
The Factual Basis for Indigenous Land Rights
}

Kent McNeil

Osgoode Hall Law School of York University, kmcneil@osgoode.yorku.ca

Source Publication:

Monash University Law Review (forthcoming)

Follow this and additional works at: https://digitalcommons.osgoode.yorku.ca/scholarly_works

Part of the Indigenous, Indian, and Aboriginal Law Commons

\section{Repository Citation}

McNeil, Kent, "The Factual Basis for Indigenous Land Rights" (2021). Articles \& Book Chapters. 2833.

https://digitalcommons.osgoode.yorku.ca/scholarly_works/2833

This Article is brought to you for free and open access by the Faculty Scholarship at Osgoode Digital Commons. It has been accepted for inclusion in Articles \& Book Chapters by an authorized administrator of Osgoode Digital Commons. 


\title{
The Factual Basis for Indigenous Land Rights
}

\author{
Kent McNeil* \\ April 2021, forthcoming in the Monash University Law Review
}

\begin{abstract}
Groundbreaking judgments in Australia and Canada in the 1990s reveal that Indigenous land rights depend on evidence of Indigenous occupation and law when the British Crown asserted sovereignty. Looking back at earlier Indigenous rights decisions, it is apparent that they were not based on facts, but on prejudicial and erroneous assumptions about Indigenous peoples. In St. Catherine's Milling (1888), Lord Watson said the rights of the Ojibwe Indians were based solely on the goodwill of the Crown, a conclusion that evidently stemmed from the trial judge's racist assessment of Ojibwe society. In Cooper v Stuart (1889), Lord Watson wrongly described New South Wales as a "territory practically unoccupied, without settled inhabitants or settled law," at the time it became a British colony.
\end{abstract}

This article demonstrates that what was missing in the 1880s was not law supporting Indigenous land rights, but rather evidence that should have led to the application of existing law. Erroneous factual assumptions resulted in legal precedents that led to the denial of Indigenous rights for around a century. Nor is the impact of these precedents entirely spent. Even today, false arguments are made that there was no basis in nineteenth-century common law for Indigenous land rights.

\section{Text}

\footnotetext{
* Emeritus Distinguished Research Professor, Osgoode Hall Law School, York University, Toronto, Canada. My sincere thanks go to the University of Saskatchewan College of Law for generously funding my research for this article as the Law Foundation of Saskatchewan H Robert Arscott Chair from July 1 to December 31, 2019, and to the Indigenous Law Centre in Saskatoon for providing me with support and a very congenial space in which to work. I would also like to thank Kerry Wilkins and David Yarrow for their very helpful feedback on a draft of the article and two anonymous reviewers for their perceptive comments and suggestions.
} 
In the past 30 years, the land rights of the Indigenous peoples of Australia and Canada have been belatedly acknowledged and defined by the highest courts in these countries. In 1992 in Mabo v Queensland [No 2], ${ }^{1}$ the High Court of Australia decided for the first time that, in the absence of extinguishment, the Torres Strait Islanders, and hence Indigenous peoples elsewhere in Australia, have Native title at common law to the lands they occupied and used in accordance with their own laws and customs at the time of acquisition of sovereignty by the British Crown. In Canada, although the Supreme Court had acknowledged the existence of Indigenous land rights earlier, ${ }^{2}$ those rights were first defined by the Court in 1997 in Delgamuukw v British Columbia ${ }^{3}$ and the first declaration of Aboriginal title occurred as recently as 2014 in Tsilhqot'in Nation v British Columbia. ${ }^{4}$ A major impediment to the acknowledgement of common law Indigenous land rights in Canada was the Privy Council's decision in St. Catherine's Milling and Lumber Company $v$ The Queen, ${ }^{5}$ where Lord Watson had attributed whatever land rights the Ojibwe people of north-western Ontario possessed to the goodwill of the Crown as expressed in the Royal Proclamation of 1763. In Australia, judicial denial of Indigenous land rights stemmed largely from the Privy Council's 1889 decision in Cooper $v$ Stuart ${ }^{6}$ in which Lord Watson described the colony of New South Wales as "practically unoccupied, without settled inhabitants or settled law" at the time it was colonized by Great Britain. ${ }^{7}$

\footnotetext{
1 (1992) 175 CLR 1 [Mabo No 2].

${ }^{2}$ E.g. in Calder v Attorney-General of British Columbia [1973] SCR 313 [Calder]; Guerin v The Queen [1984] 2 SCR 335 [Guerin]. ${ }^{3}$ [1997] 3 SCR 1010 [Delgamuukw]. ${ }^{4}$ [2014] 2 SCR 257 [Tsilhqot'in Nation].

${ }^{5}$ (1888) 14 App Cas 46 [St. Catherine's]. ${ }^{6}$ (1889) 14 App Cas 286.

${ }^{7}$ Ibid at 291.
} 
This article examines Lord Watson's decisions in these two cases from the 1880 s in order to understand the Privy Council's reasons for denying common law land rights to the Indigenous peoples of Canada and Australia. Although some commentators have suggested that the decisions were based on a lack of law supporting these rights, ${ }^{8}$ my analysis suggests that what was missing in these cases was not law but evidence. In other words, the Privy Council was unable to acknowledge Indigenous land rights that had not been recognized or granted by the Crown (e.g. by the Royal Proclamation in Canada) because the factual basis for these rights had not been laid down at trial. The article will start by examining the St. Catherine's case, then discuss Cooper $v$ Stuart, and finish with a comparison of the more recent case law.

\section{The St. Catherine's Case}

\section{(a) Backgound and Judgments}

The St. Catherine's case arose from a constitutional property dispute between the Province of Ontario and the Dominion of Canada over which government benefitted from the surrender of Indigenous land rights to the Crown by treaty. ${ }^{9}$ No Indigenous people were involved in the case, either as

\footnotetext{
${ }^{8}$ E.g. see PG McHugh, Aboriginal Title: The Modern Jurisprudence of Tribal Land Rights (Oxford: Oxford University Press, 2011); Paul McHugh \& Lisa Ford, "Settler Sovereignty and the Shapeshifting Crown," in Lisa Ford \& Tim Rowse, eds, Between Indigenous and Settler Governance (Abingdon, UK: Routledge, 2013), 23; David V Williams, "The Role of Legal History in Developing New Zealand Common Law Following Paki (No 2)" [2016] NZ L Rev 755 at 777-87.

${ }^{9}$ See Anthony J Hall, “The St. Catherine's Milling and Lumber Company versus the Queen: Indian Land Rights as a Factor in Federal-Provincial Relations in Nineteenth-Century Canada", in Kerry Abel \& Jean Friesen, eds, Aboriginal Resource Use in Canada: Historical and Legal Aspects (Winnipeg: University of Manitoba Press, 1991), 267-86; Sidney L Harring, White Man's Law: Native People in Nineteenth-Century Canadian Jurisprudence (Toronto: University of Toronto Press, 1998), 125-47. This article draws on the detailed discussion of the case, including the historical and political background, in Kent McNeil, Flawed Precedent: The St. Catherine's Case and Aboriginal Title (Vancouver: UBC Press, 2019).
} 
parties or witnesses, even though the nature of Aboriginal title to land was a major issue. The Saulteaux tribe of the Ojibwe (Anishinaabe) people, who had entered into Treaty 3 in 1873, were no doubt unaware even that the case was been litigated. By the treaty's written terms, ${ }^{10}$ they had agreed to give up their land rights in return for reserves and other benefits, while retaining hunting and fishing rights over the surrendered territory. ${ }^{11}$ The lands in question in the case are in northwestern Ontario between Lake Superior and the Lake of the Woods, within the geographical limits of the treaty.

The case was triggered by a grant in 1883 by the Crown in right of Canada to the St. Catherine's Milling and Lumber Company of timber harvesting rights near Wabigoon Lake. Ontario commenced legal action against the company by way of an information of intrusion (a prerogative action equivalent to an action for trespass), alleging that the timber licence was void because the land, and therefore the standing timber, belonged to the Crown in right of the province, not the federal Crown. Ontario claimed that it owned the land by virtue of section 109 of the British North America Act, 1867 (now the Constitution Act, 1867), ${ }^{12}$ which provides that all public lands belonging to the provinces prior to Confederation continue to belong to them thereafter, with certain exceptions such as custom houses, post

\footnotetext{
${ }^{10}$ Treaty 3, online: https://www.aadnc-aandc.gc.ca/eng/1100100028675/1100100028679. On negotiation of the treaty, see Alexander Morris, The Treaties of Canada with the Indians of Manitoba and the North-West Territories (Toronto: Belfords, Clark and Co., 1880; facsimile edition, Toronto: Coles Publishing Co, 1979), 44-76; Brian Walmark, "Alexander Morris and the Saulteaux: The Context and Making of Treaty Three, 1869-73", MA thesis, Department of History, Lakehead University, 1994, online: http://www.collectionscanada.ca/obj/s4/f2/dsk3/ftp04/MQ52083.pdf.

${ }^{11}$ The Saulteaux claim that the written terms do not accurately reflect the actual agreement, as their intention was to share the land and resources rather than surrender them completely. For their understanding of the treaty, see Tim Holzkamm \& Leo Waisberg, "We Have Kept Our Part of the Treaty". The Anishinaabe Understanding of Treaty \#3 (Kenora, ON: Grand Council Treaty \#3, 2011), online: http:// www.ocsta.on.ca/ocsta/wp-content/uploads/2017/01/We-Have-Kept-Our-Part-Of-The-Treaty-Booklet.pdf. See also Brittany Luby, “'The Department Is Going Back on These Promises': An Examination of Anishinaabe and Crown Understandings of Treaty" (2010) 30:2 Can J Native Studies 203; Kate Gunn, "Agreeing to Share: Treaty 3, History and the Courts" (2018) 51 UBC L Rev 75.

1230 \& 31 Vict, c 3 (Imp).
} 
offices, and military installations that were not relevant to the case. ${ }^{13}$ The company, which became the proxy for the Canadian government, ${ }^{14}$ defended by alleging in part that the Saulteaux had owned the lands prior to the treaty and by that document had transferred them to the federal government that had negotiated the treaty and accepted the surrender of the lands. The Privy Council found for the province, holding that the surrender to the Crown had extinguished the Aboriginal title and caused the underlying title that the Crown in right of Ontario had by virtue of section 109 to become plenum dominium - complete ownership. ${ }^{15}$ Lord Watson described the Crown's underlying title prior to the treaty as "a present proprietary estate in the land" that was "substantial and paramount."16

The "tenure of the Indians," on the other hand, was more limited - it was "a personal and usufructuary right, dependent upon the good will of the Sovereign."17 Lord Watson based this description of Aboriginal title on his interpretation of the Royal Proclamation of 1763, which had reserved unceded Indian lands for their use and forbade private purchases of and settlement on those lands. ${ }^{18}$ He stated that the Saulteaux's "possession, such as it was, can only be ascribed to the general provisions made by the royal proclamation in favour of all Indian tribes then living under the sovereignty and protection of the British Crown." 19 In other words, any land rights the Indians had were the result of a positive act of the Crown - they were based on the Crown's bounty as sovereign. But what led the Privy Council to

\footnotetext{
${ }^{13}$ Ibid. The exceptions are listed in the Third Schedule to the Act: see s 108.

${ }^{14}$ Canada only joined the action on the final appeal to the Privy Council in 1888.

${ }^{15}$ St. Catherine's, above note 5 at 55.

${ }^{16} \mathrm{Ibid}$ at 55, 58.

${ }^{17}$ Ibid at 54.

18 The Royal Proclamation is reproduced in RSC 1985, App II, No 1.

${ }^{19}$ St. Catherine's, supra note 5 at 54.
} 
ignore other potential sources of Aboriginal title, such as Indigenous law and the common law?

The answer lies in the factual findings of the trial judge, Chancellor Boyd. In his view, the

Indian peoples were found scattered wide-cast over the continent, having, as a characteristic, no fixed abodes, but moving as the exigencies of living demanded. As heathens and barbarians it was not thought that they had any proprietary title to the soil, nor any such claim thereto as to interfere with the plantations, and the general prosecution of colonization. ${ }^{20}$

He said the Indians on reserves were "regarded no longer as in a wild and primitive state, but as in a condition of transition from barbarism to civilization." 21 Compared with them, the Saulteaux who entered into Treaty 3 were "wild and primitive" - they were "scattered bands of Ojibbeways, most of them presenting a more than usually degraded Indian type."22

Chancellor Boyd's opinions of Indians in general and the Saulteaux in particular sound very much like the assessments of the social evolution theorists who had published speculative books on human societies in the decade before the St. Catherine's case went to court. ${ }^{23}$ Influenced by the publication of Charles Darwin's On the Origin of Species in 1859, theorists such as Edward Tylor, a leading proponent of social evolution, wrote in 1871 that progress and decline consisted of

... movement along a measured line from grade to grade of actual savagery, barbarism, and civilization. The thesis which I

\footnotetext{
${ }^{20}$ St. Catharine's Milling and Lumber Company v The Queen (1885), 10 OR 196 (Ch) at 206 [St. Catharine's $\mathrm{Ch}]$.

${ }^{21}$ Ibid. at 228.

${ }^{22}$ Ibid at 227.

${ }^{23}$ See Robert F Berkhofer Jr, The White Man's Indian: Images of the American Indian from Columbus to the Present (New York: Alfred A Knopf, 1978), 33-69; George W Stocking Jr, Victorian Anthropology (New York: Free Press, 1987); Marvin Harris, The Rise of Anthropological Theory: A History of Theories of Culture, updated ed (Walnut Creek, CA: AltaMira Press, 2001), 142-216.
} 
venture to sustain, within limits, is simply this, that the savage state in some measure represents an early condition of mankind, out of which the higher culture has gradually been developed or evolved. ${ }^{24}$

Applying these ethnocentric standards of measurement, Lewis Henry Morgan concluded in a book published in 1877 that "the American aborigines" had

... commenced their career on the American continent in savagery; and, although possessed of inferior mental endowments, the body of them had emerged from savagery and attained to the Lower Status of barbarism; whilst a portion of them, the Village Indians of North and South America, had risen to the Middle Status. ${ }^{25}$

Similarly, in Boyd C's view, Indians who had not yet settled on reserves were "wild" and "barbaric", and so were too "primitive" to have any rights to the lands they supposedly wandered over.

So what evidence was there to support Chancellor Boyd's assessment of the Saulteaux? The answer is, none at all. The only witness called in the St. Catherine's case was Alexander Morris, the head commissioner who negotiated Treaty 3 on behalf of the government of Canada. His evidence, the transcript of which is a scant two pages long, merely affirmed that the treaty had been entered into. ${ }^{26}$ It did not provide any insight into the Saulteaux way of life or their relationship with the land. Morris's book, The Treaties of Canada with the Indians of Manitoba and the North-West

\footnotetext{
${ }^{24}$ Edward B Tylor, Primitive Culture: Researches into the Development of Mythology, Philosophy, Religion, Art, and Custom, 2 vols (London: John Murray, 1871), I, 28.

${ }^{25}$ Lewis H Morgan, Ancient Society: or Researches in the Lines of Human Progress from Savagery, through Barbarism to Civilization (New York: Henry Holt \& Company, 1877), 40. Morgan subdivided Tylor's categories of "savagery" and "barbarism" into three levels: lower, middle, and upper.

${ }^{26}$ The transcript of Morris's testimony is in the Supreme Court Appeal Book, In the Supreme Court of Canada, Appeal from the Court of Appeal for Ontario, Between The Queen and St. Catharines Milling and Lumber Company: Case (Toronto: Dudley \& Burns, 1886), 10-12.
} 
Territories, ${ }^{27}$ containing an account of the treaty negotiations, was also put in as evidence, but Boyd $\mathrm{C}$ did not refer to it in his judgment and it does not appear to have influenced his decision. Apart from Morris's book and brief testimony, the case was argued entirely on documents submitted by counsel, none of which appear to shed light on the Saulteaux whose land rights were at issue in the case. ${ }^{28}$

So Chancellor Boyd's perception of the Saulteaux as "wild", "primitive", and "degraded" must have been based on assumptions rather than facts - assumptions derived from social evolution theory and the racist Eurocentric prejudices of the time. Those assumptions did not correspond with the reality of Saulteaux life, which was governed by laws and involved intensive use of and complex relationships with the land and the natural resources in Saulteaux territory. ${ }^{29}$ And yet those erroneous assumptions

\footnotetext{
${ }^{27}$ Supra note 10.

${ }^{28}$ Counsel for the St. Catherine's Milling and Lumber Company relied in part on the judgments of Marshall CJ in the US Supreme Court, particularly Cherokee Nation v Georgia, 5 Pet (30 US) 1 (1831), and Worcester $v$ Georgia, 6 Pet (31 US) 515 (1832). Boyd C cited instead a passage from Johnson v M'Intosh, 8 Wheat (21 US) 543 (1823) at 595-96, where Marshall CJ stated: "According to the theory of the British constitution, all vacant lands are vested in the crown.... So far as respected the authority of the crown, no distinction was taken between vacant lands and lands occupied by the Indians." While the Chancellor acknowledged that Marshall CJ had also said that "the absolute title of the Crown [is] subject only to the Indian right of occupancy" (Johnson v M'Intosh at 588), in his opinion this "primitive right of occupancy," as he called it, was not a legal right: "the claim of the Indians by virtue of their original occupation is not such as to give any title to the land itself, but only serves to commend them to the consideration and liberality of the Government upon their displacement": St. Catharine's Ch, supra note 20 at 209, 229, 234. In so deciding, Boyd C conveniently disregarded other passages in Johnson v M'Intosh, such as: "They [the original inhabitants of North America] were admitted to be the rightful occupants of the soil, with a legal as well as just claim to retain possession of it, and to use it according to their own discretion" (at 574). Justice Strong, in the appeal to the Supreme Court of Canada, relied on Marshall CJ's judgments, as well as on Mitchell v United States, 9 Pet (34 US) 711 (1835), to reach a conclusion opposite to that of Boyd C, but Strong J was dissenting: (1887) 13 SCR 577 at 610-12. Before the Privy Council, these American cases were all cited again by counsel for Canada and the company, but they were not mentioned in Lord Watson's judgment. That is hardly surprising, as it would have been highly unlikely for Her Majesty's Judicial Committee of the Privy Council to rely on the views of the US Supreme Court on the nature of the Crown's title to land in British North America.

${ }^{29}$ For early works on the Ojibwe who include the Saulteaux, see Nicolas Perrot, Memoire sur les moeurs, coutumes et religion des sauvages de l'Amérique septentrionale (Paris: R.P. Tailhan, 1864, written before 1720 but previously unpublished), English translation in Emma Helen Blair, ed, The Indian Tribes of the Upper Mississippi Valley and Region of the Great Lakes (Lincoln: University of Nebraska Press, 1996), 22-272; George Copway, The Traditional History and Characteristic Sketches of the Ojibway Nation (Boston:
} 
were part of the "factual" record that was relied on by the appeal judges. In the Ontario Court of Appeal, Chief Justice Hagarty praised the Chancellor, stating that he had mapped out the field "with so much care and perspicacity as to very much reduce the labours of subsequent investigators. We may fully accept his historical treatment of the subject from the earliest period down to the Confederation Act of 1867." ${ }^{30}$ Justice Patterson echoed these views. $^{31}$ In the Supreme Court of Canada, Justice Taschereau likewise observed that Boyd C's treatment of the issues was so thorough that he had little to add. ${ }^{32}$ Justice Henry stated that he "entirely approve[d] of the judgment of the learned chancellor, which, I think, embraces all the important points in the case." ${ }^{33}$ Reflecting the language in Boyd C's judgment, he concluded that "all wild lands, including those held by nomadic tribes of Indians, were the property of the crown."34 "The Indians," he said, "were not in possession of any particular portion of the land," 35 a factual finding that must have been based either on the Chancellor's assumptions about the Saulteaux's relationship with the land or Justice

Benjamin B Mussey \& Co, 1851); Henry Rowe Schoolcraft, Historical and Statistical Information, Respecting the History, Conditions, and Prospects of the Indian Tribes of the United States (Philadelphia: Lippincott, Grambo, 1851); William W Warren, History of the Ojibways, Based upon Traditions and Oral Statements (St. Paul: Minnesota Historical Society, 1885), reprinted as History of the Ojibwa Peoples, with an Introduction by W Roger Buffalohead (St. Paul: Minnesota Historical Society Press, 1984). For more recent discussions, see Harold Hickerson, "Land Tenure of the Rainy Lake Chippewa at the Beginning of the 19th Century" (1967) 2:4 Smithsonian Contributions to Anthropology 41; Robert E Ritzenthaler, "Southwestern Chippewa", in Bruce Trigger, ed, Handbook of North American Indians, vol 15, Northeast, (Washington: Smithsonian Institution, 1978), 743; D Peter MacLeod, "The Anishinabeg Point of View: The History of the Great Lakes Region to 1800 in Nineteenth Century Mississauga, Odawa, and Ojibwa Historiography" (1992) 73 Can Hist Rev 194; Charles A Bishop, "Territorial Groups Before 1821: Cree and Ojibwa", in June Helm, ed, Subarctic, vol 6, Handbook of North American Indians, (Washington: Smithsonian Institution, 1981), 158; Tim E Holzkamm \& Leo G Waisberg, "Native American Utilization of Sturgeon", in Greg TO LeBreton, F William H Beamish \& R Scott McKinley, eds, Sturgeons and Paddlefish of North America (New York: Kluwer Academic Publishers, 2004), 22 at 27-35; John Borrows, Canada's Indigenous Constitution (Toronto: University of Toronto Press, 2010), especially 77-84.

${ }^{30}$ St. Catharine's Milling and Lumber Company v The Queen (1886), 13 OAR 148 at 148.

${ }^{31} \mathrm{Ibid}$ at 168-69.

${ }^{32}$ St. Catharine's Milling and Lumber Company v The Queen (1887), 13 SCR 577 at 643.

${ }^{33}$ Ibid at 639.

${ }^{34}$ Ibid.

${ }^{35}$ Ibid at 641 . 
Henry's own misinformed perceptions. Even Justice Strong, who wrote a forceful dissent, seems to have accepted that Saulteaux society was "lawless". 36

Lord Watson for the Privy Council avoided the racist language used by Chancellor Boyd and did not heap praise on his judgment as some of the Court of Appeal and Supreme Court judges had done. He nonetheless concluded, as we have seen, that the Saulteaux's "possession, such as it was, can only be ascribed to the general provisions made by the royal proclamation in favour of all Indian tribes then living under the sovereignty and protection of the British Crown." 37 He therefore assumed that their occupation and use of the land did not amount to the kind of possession that would have given them real property rights at common law. In the English legal system, possession is a root of title: anyone in possession of land is presumed to have good title, rebuttable only by proof by another claimant that he or she has a better title. ${ }^{38}$ Even a wrongdoer who has been in adverse possession for less than the statutory limitation period has a title valid against everyone (including the Crown ${ }^{39}$ ) except the true owner or others who can establish that they have a better title. ${ }^{40}$

Moreover, possession does not require any particular use of the land. In Red House Farms Ltd $v$ Catchpole, ${ }^{41}$ the English Court of Appeal held

\footnotetext{
${ }^{36}$ Ibid at 614.

${ }^{37}$ St. Catherine's, supra note 5 at 54 [my emphasis].

${ }^{38}$ See Frederick Pollock \& Robert Samuel Wright, An Essay on Possession in the Common Law (Oxford: Clarendon Press, 1888), 91-95. This is old law, going back to the medieval concept of seisin, the real actions, and the possessory assizes: see AWB Simpson, A History of the Land Law (Oxford: Clarendon Press, 1986), 37-44, 151-52; Kent McNeil, Common Law Aboriginal Title (Oxford: Clarendon Press, 1987), ch 2 [McNeil, Common Law Aboriginal Title].

${ }^{39}$ Perry v Clissold [2007] AC 73 (PC).

${ }^{40}$ See Graham v Peat (1801) 1 East 244 (102 ER 95); Asher v Whitlock (1865) LR 1 QB 1; Bristow v Cormican (1878) 3 App Cas 641 (HL Ir) per Lord Cairns at 651, Lord Hatherley at 657, Lord Blackburn at 660.

41 (1976) 244 EG 295.
} 
that hunting on marshy land and giving others permission to hunt were sufficient to establish adverse possession. In the Crown's overseas dominions, "the conditions of life and habits and ideas of the people" are taken into account. ${ }^{42}$ In Wuta-Ofei $v$ Danquah, ${ }^{43}$ where the acts of occupation relied upon were placing markers at the four corners of the land, keeping watch over it, and warning intruders off, the Privy Council found those acts to be sufficient for possession, even though no use was being made of the land. Lord Guest stated that their "Lordships do not consider that in order to establish possession it is necessary for a claimant to take some active step in relation to the land such as enclosing the land or cultivating it. The type of conduct which indicates possession must vary with the type of land." ${ }^{44}$ So if adequate evidence of Saulteaux occupation in accordance with their way of life had been presented at the St. Catherine's trial, they should have been accorded the possession necessary for title at common law. ${ }^{45}$

\section{(a) Case Law from other Dominions of the Crown}

Lord Watson must have assumed that the Saulteaux did not have laws of their own according them property rights that would have continued after the Crown's acquisition of sovereignty. Several cases before and after St. Catherine's, some of which were decided by the Privy Council, accepted the applicability of local law to uphold land rights in the Crown's dominions.

\footnotetext{
${ }^{42}$ Cadija Umma v S Don Manis Appu [1939] AC 136 (PC, on appeal from Ceylon) at 141-42, per Sir George Rankin.

${ }^{43}$ [1961] 1 WLR 1238.

${ }^{44} \mathrm{Ibid}$ at 1243 . Note that most of the land within Treaty 3 is rocky terrain covered by forest, lakes, and rivers.

${ }^{45}$ For detailed discussion of possession as a source of Indigenous land rights, see McNeil, Common Law Aboriginal Title, supra note 38, especially ch 7.
} 
Early examples concern the English conquests of Ireland and Wales where English law had been introduced but local customary law was held to continue to the extent that it was not unreasonable and did not offend English conceptions of justice. ${ }^{46}$ Similarly, on the Isle of Man, acquired by conquest by Edward III in the fourteenth century, the local-law right of the inhabitants to dig clay and sand to make bricks for sale was held to prevail against the Crown by the Privy Council in Attorney-General for the Isle of Man v Mylchreest ${ }^{47}$ decided just nine years before St. Catherine's. Crown grants of land were therefore subject to this right. The decision was delivered by Sir Montague E. Smith, who also sat on the St. Catherine's appeal. He observed that "[n]umerous witnesses, many of them of great age, proved that clay and sand had been largely dug up, used, and sold by the owners of the customary tenements." 48 The case in favour of the inhabitants was thus decided on the evidence of customary law, in the absence of which they would not have succeeded. ${ }^{49}$

Appeals to the Privy Council from the Crown's overseas colonies reveal the same acceptance of local land rights, whether based on custom or longstanding possession, provided they are established by evidence. Attorney-General for British Honduras $v$ Bristowe, ${ }^{50}$ decided by the Privy Council in 1880, involved an information of intrusion brought by the Crown to acquire possession of land that had been devised to a community of

\footnotetext{
${ }^{46}$ See Case of Tanistry (1608) Davis 28 (80 ER 516) (KB), $4^{\text {th }}$ ed (Dublin, 1762) 78 (for English translation from law French); Witrong v Blany (1674) 3 Keb 401 (84 ER 789).

47 (1879) 4 App Cas 294.

${ }^{48}$ Ibid at 300.

${ }^{49}$ Compare Attorney-General v Jones (1862) 33 LR Ex 249, involving an information of intrusion (as in Mylchreest and St. Catherine's), where the Crown claimed a prerogative right to a stretch of foreshore in Wales. The defendant pleaded but was unable to establish a right based on the ancient Welsh law of Howel Dda because the court did not accept the evidence of it: ibid at $257 \mathrm{n} 8$.

${ }^{50}$ (1880) 6 App Cas 143 [Bristowe]. For more detailed discussion, see McNeil, Common Law Aboriginal Title, supra note 38 at 141-47.
} 
former slaves by their master's will. At trial, Chief Justice Parker of the British Honduras Supreme Court decided that the defendants had possessory rights based on evidence of "continued occupancy and long industrial possession," judgment delivered once again by Sir Montague E. Smith, upheld this decision on the basis that the defendants had title by adverse possession against the Crown for sixty years, the statutory limitation period set by the English Nullum Tempus Act ${ }^{52}$ that applied in British Honduras. While not disagreeing with Parker CJ's decision that the defendants had title "by first occupancy or otherwise," their Lordships found it unnecessary to decide the case on that basis, given the expiry of the statutory limitation period. ${ }^{53}$ It is nonetheless evident from their judgment that, had the statutory defence not been available, they would have found for the defendants in any case on the basis of their longstanding possession, as had Parker CJ.

Privy Council decisions from New Zealand and Africa not long after St. Catherine's provide clear examples of acceptance of Indigenous land rights based on customary law. In Nireaha Tamaki v Baker, ${ }^{54}$ decided by the Privy Council in 1901, a member of the Rangitāne tribe in New Zealand claimed native title on behalf of his tribe to a parcel of land in accordance with Māori customs and usages to prevent the Crown from selling it. Their Lordships overturned the ruling of the New Zealand courts that they had no jurisdiction to question an assertion of title by the Crown or decide questions

\footnotetext{
${ }^{51}$ Bristowe, supra note 50 at 155 . Parker CJ's unreported judgment is in [1880] 10 Printed Cases in Appeals, Privy Council, Case 46, Record of Proceedings, in the Privy Council Office, London, copy on file with the author.

529 Geo III, c 16, amended 24 \& 25 Vict, c 62.

${ }^{53}$ Bristowe, supra note 50 at 155.

${ }^{54}$ [1901] AC 561[Nireaha Tamaki]. This decision effectively affirmed The Queen v Symonds (1847) [18401932] NZPCC 387 (NZSC) and overruled the contrary decision in Wi Parata $v$ Bishop of Wellington (1877) 3 NZ Jur (NS) SC 72 (NZSC).
} 
of title between the Crown and the Māori. ${ }^{55}$ Lord Davey stated that "[t]heir Lordships think that the Supreme Court are bound to recognise the fact of the 'rightful possession and occupation of the natives' until extinguished in accordance with law in any action in which [native] title is involved." 56 If the appellant was able to prove that "he and the members of his tribe are in possession and occupation of the lands in dispute under a native title which has not been lawfully extinguished, he can maintain this action to restrain an unauthorized invasion of his title." 57 This decision, rendered just thirteen years after St. Catherine's in relation to events from the 1870 s to 1890 s, reveals that Aboriginal title, if established by sufficient evidence of occupation of land under Indigenous customs and usages, entails legal rights to possession enforceable against the Crown. ${ }^{58}$

In Re Southern Rhodesia, ${ }^{59}$ a 1919 Privy Council decision involving the effect of the Crown's acquisition of sovereignty by conquest, Lord Sumner commented on the rights of Indigenous peoples in British colonies generally:

The estimation of the rights of aboriginal tribes is always inherently difficult. Some tribes are so low in the scale of social organization that their usages and conceptions of rights and duties are not to be reconciled with the institutions or the legal ideas of civilized society.... On the other hand, there are indigenous peoples whose legal conceptions, though differently

\footnotetext{
${ }^{55}$ See also Wallis v Solicitor-General for New Zealand [1903] AC 173 (PC).

${ }^{56}$ Nireaha Tamaki, supra note 54 at 578.

${ }^{57}$ Ibid.

${ }^{58}$ See Simon Young, The Trouble with Tradition: Native Title and Cultural Change (Leichhardt, NSW: Federation Press, 2008), 64-68 [Young, The Trouble with Tradition]; Ulla Secher, Aboriginal Customary Law: A Source of Common Law Title to Land (Oxford: Hart Publishing, 2014), 71-77. More recently in Attorney-General v Ngati Apa [2003] 3 NZLR 643, the New Zealand Court of Appeal affirmed the existence of Māori land rights based on tikanga Māori, which includes law and practices: per Elias CJ at paras 14, 32, 49, 89, Gault P at para 101, Tipping J at para 184.

${ }^{59}$ [1919] AC 211. As the Privy Council decided that Southern Rhodesia became a British colony in 1893, the time for assessment of pre-existing property rights of the Indigenous inhabitants would have been just five years after their Lordships decided the St. Catherine's case.
} 
developed, are hardly less precise than our own. When once they have been studied and understood they are no less enforceable than rights arising under English law. ${ }^{60}$

These remarks, which show the influence of social evolution theory, have been justly criticized for suggesting that some Indigenous peoples were too "primitive" to have legal rights to the lands they occupied and used. ${ }^{61}$ However, the passage also reveals that Indigenous peoples can have land rights that are enforceable in common law courts once their legal conceptions have been "studied and understood," which in the context of legal proceedings means once adequate evidence of them has been presented to the court by Indigenous witnesses, experts, and relevant documents. In Re Southern Rhodesia, Lord Sumner said the evidence of Indigenous property rights was "slender", so "it was really a matter of conjecture to say what the rights of the original "natives' were." ${ }^{2}$ In the St. Catherine's case, evidence of Ojibwe law was entirely absent, and yet Chancellor Boyd did not hesitate to fill this evidentiary void himself with erroneous assumptions about North American Indigenous societies generally and Ojibwe society in particular.

Lord Sumner's acceptance of the enforceability of Indigenous land rights originating in Indigenous law was given effect by the Privy Council two years later in Amodu Tijani v Secretary, Southern Nigeria, ${ }^{63}$ which involved a claim for compensation by a Nigerian chief for lands taken for

\footnotetext{
${ }^{60} \mathrm{Ibid}$ at 233-34.

${ }^{61}$ E.g. see Catherine Bell \& Michael Asch, "Challenging Assumptions: The Impact of Precedent in Aboriginal Rights Litigation", in Michael Asch, ed, Aboriginal and Treaty Rights in Canada: Essays on Law, Equality, and Respect for Difference (Vancouver: UBC Press, 1997), 38, especially 57-64; Michael Asch, "First Nations and the Derivation of Canada's Underlying Title: Comparing Perspectives on Legal Ideology", in Curtis Cook \& Juan D Lindau, eds, Aboriginal Rights and Self-Government: The Canadian and Mexican Experience in North American Perspective (Montreal \& Kingston: McGill-Queen's

University Press, 2000), 148, especially 151-54, 157.

${ }^{62}$ Re Southern Rhodesia, above note 59 at 232-33.

63 [1921] 2 AC 399 [Amodu Tijani].
} 
public purposes in 1913 by the British Crown at Apapa in the territory the White Cap Chiefs of Lagos ceded to the Crown in 1861. Viscount Haldane held that the cession passed the "radical or ultimate title to the land" to the Crown but did not affect the communal rights of the inhabitants under their own laws. "A4 "A mere change in sovereignty," he said, "is not to be presumed as meant to disturb rights of private owners; and the general terms of a cession are prima facie to be construed accordingly." ${ }^{\prime 2} \mathrm{He}$ also cautioned against trying to fit the rights of Indigenous peoples' under their own legal systems into the conceptual framework of the common law:

Their lordships make the preliminary observation that in interpreting the native title to land, not only in Southern Nigeria, but other parts of the British Empire, much caution is essential. There is a tendency operating at times unconsciously, to render that title conceptually in terms which are appropriate only to systems which have grown up under English law. But this tendency has to be held in check closely. As a rule, in the various systems of native jurisprudence throughout the Empire, there is no such full division between property and possession as English lawyers are familiar with. A very usual form of native title is that of a usufructuary right, which is a mere qualification of or burden on the radical or final title of the Sovereign where that exists. In such cases the title of the Sovereign is a pure legal estate, to which beneficial rights may or may not be attached. ${ }^{66}$

Viscount Haldane referred to the St. Catherine's case in this context, where the characterization of Aboriginal title as usufructuary was based on the Royal Proclamation of 1763, but what his judgment in Amodu Tijani reveals

\footnotetext{
${ }^{64} \mathrm{Ibid}$ at 407 .

${ }^{65} \mathrm{Ibid}$. This is the same rule that had been applied much earlier in the Case of Tanistry and Witrong $v$ Blany, supra note 46. Chancellor Boyd applied it himself to the pre-existing land rights of the French Canadians in Drulard v Welsh (1906) 11 OLR 647 (Ont Div Ct), reversed on appeal on the ground that the evidence of the plaintiff's title was inadequate: (1907) 14 OLR 54 (Ont CA). The rule applies in international law as well as domestic law: see DP O'Connell, State Succession in Municipal and International Law, 2 vols (Cambridge: Cambridge University, 1967), I, 237-50.

${ }^{66}$ Amodu Tijani, supra note 63 at 402-03.
} 
is that a usufructuary or other land right could also be derived from a system of "native jurisprudence," as long as adequate evidence of that jurisprudence is presented to the court.

The evidence in Amodu Tijani demonstrated that, under Nigerian customary law, the Lagos chiefs held land rights for the benefit of the members of their community. ${ }^{67}$ Consequently, the Privy Council decided that compensation for the full value of the expropriated land had to be paid to the plaintiff chief who was then obliged to distribute it among the members of his community in accordance with their customary rights. ${ }^{68}$ Their Lordships accordingly acknowledged that the usufructuary rights under customary law, as revealed by the evidence, amounted to the entire beneficial interest in the land. These rights continued after the cession of sovereignty to the Crown in $1861 .^{69}$ Re Southern Rhodesia and Amodu Tijani are therefore consistent with regard to the law: they both held that the land rights of Indigenous peoples under ascertainable customary law continue after Crown acquisition of sovereignty. The difference between them is that in Re Southern Rhodesia there was insufficient evidence of the land rights of the inhabitants whereas in Amodi Tijani the Privy Council found the evidence of the existence and nature of the local land rights to be adequate for them to be enforceable against the Crown.

\section{(a) Conclusions Regarding the St. Catherine's Case}

\footnotetext{
${ }^{67}$ The evidence consisted mainly of a Report on Land Tenure in West Africa by Chief Justice Rayner, supported by "various documents, records and decisions": ibid at 404-05.

${ }^{68}$ Ibid at 411.

${ }^{69} \mathrm{Ibid}$ at 409-11.
} 
In St. Catherine's, Lord Watson's conclusion that the Saulteaux's possession could only be attributed to the Royal Proclamation of 1763 amounted to a denial of common law rights based on possession of land and of rights based on Indigenous law. Chancellor Boyd's remarks about the "primitive" nature of Saulteaux society and their lack of attachment to the land would have provided the Privy Council with a false factual basis for reaching these conclusions. The problem here, as we have seen, is that no evidence was presented in the case to support Boyd C's negative assessment of Saulteaux society and land use. Instead, his views must have been based on erroneous assumptions about Indigenous societies in North America that were widely accepted in Euro-Canadian circles at the time. If adequate evidence of Saulteaux land use and law had been presented at trial, the Privy Council appeals we have examined from the Isle of Man, British Honduras, New Zealand, and Africa suggest that their Lordships' assessment of their land rights could have been very different. Instead, Lord Watson's decision on the source and nature of Aboriginal title in Canada, like his judgment with regard to the Indigenous peoples of Australia a few months later in Cooper $v$ Stuart, became the legal precedent on these matters for almost a hundred years until his views began to be questioned in the modern case law.

\section{Cooper $v$ Stuart}

Unlike the St. Catherine's case, Cooper v Stuart had nothing to do with Indigenous land rights. Instead, it involved the validity of a reservation in an 1823 Crown grant of 1400 acres of land in the district of Sydney of "any quantity of land, not exceeding ten acres, in any part of the said grant, as 
may be required for public purposes."70 In 1882 the Crown by proclamation resumed and fenced off ten acres of this land for a public park. The plaintiff, who was the successor in title of the original grantee, brought an action for an injunction to restrain the Crown from continuing in possession and for damages. He challenged the validity of the reservation on three main grounds: (1) uncertainty, because the ten acres were not described; (2) repugnancy, because the ten acre exception was inconsistent with the grant of 1400 acres; and (3) violation of the common law rule against perpetuities, by which a property interest, to be valid, must not be capable of vesting beyond the perpetuity period of relevant lives in being at the time the interest is created plus 21 years.

The Privy Council agreed with the decisions of the Primary Judge in Equity and the Supreme Court of New South Wales on appeal in favour of the Crown. ${ }^{71}$ Ignoring the uncertainty point because it does not appear to have been argued before their Lordships, Lord Watson dismissed the repugnancy argument summarily by deciding that the reservation of ten acres operated as a defeasance rather than as an exemption. This technical point need not deter us further, as it was only in the context of the perpetuities issue that he referred to the status of New South Wales as a settled colony.

In British colonial law, overseas colonies were classified as either conquered/ceded or settled. In the former the Crown acquired sovereignty derivatively by conquest and/or cession from another sovereign, whereas in settled colonies, even if inhabited, it was presumed that there was no sovereign and so the Crown could acquire the territory by asserting its own

\footnotetext{
${ }^{70}$ Cooper v. Stuart, supra note 6 at 288.

${ }^{71}$ Both reported (1886) 7 NSWR 1.
} 
sovereignty unilaterally. The distinction had important legal consequences because in conquered and ceded colonies there was an acknowledgement of the existence of a pre-existing system of law that continued after Crown acquisition of sovereignty to the extent that it was not unreasonable or inconsistent with British conceptions of justice. In such colonies, English law would not apply (at least insofar as the local population was concerned) unless it was introduced by royal proclamation or legislative enactment. ${ }^{72}$

In Cooper v Stuart, Lord Watson noted that at the time of the grant of the land in 1823 the laws of England had not been introduced into New South Wales by Act or Ordinance. For those laws to have been in force, the colony would have to be classified as a settlement. It was in this context that his Lordship made his influential statement on the circumstances of the Indigenous inhabitants and the status of the colony:

There is a great difference between the case of a Colony acquired by conquest or cession, in which there is an established system of law, and that of a Colony which consisted of a tract of territory practically unoccupied, without settled inhabitants or settled law, at the time when it was peacefully annexed to the British dominions. The Colony of New South Wales belongs to the latter class. In the case of such a Colony the Crown may by ordinance, and the Imperial Parliament, or its own legislature when it comes to possess one, may by statute declare what parts of the common and statute law of England shall have effect within its limits. But, when that is not done, the law of England must (subject to well-established

\footnotetext{
${ }^{72}$ See Kenneth Roberts-Wray, Commonwealth and Colonial Law (New York: Praeger, 1966), 99-107, 54043; Joan Snape Marshall, "The Reception of English Law as a Modern Legal Problem", LLM thesis, University of British Columbia, 1977, Pt II, online:

https://open.library.ubc.ca/cIRcle/collections/ubctheses/831/items/1.0058335; Brian Slattery, The Land Rights of Indigenous Canadian Peoples (D Phil thesis, Oxford University 1979, published Saskatoon: University of Saskatchewan Native Law Centre, 1979), 10-35; Mark D Walters, "The 'Golden Thread' of Continuity: Aboriginal Customs at Common Law and under the Constitution Act, 1982" (1999) 44 McGill LJ 711 at 714-29; Russel Lawrence Barsh, "Indigenous Rights and the Lex Loci in British Imperial Law", in Kerry Wilkins, ed, Advancing Aboriginal Claims: Visions/Strategies/Directions (Saskatoon: Purich Publishing, 2004), 91.
} 
exceptions) become from the outset the law of the Colony, and be administered by its tribunals. ${ }^{73}$

Lord Watson elaborated on this supposed state of affairs in relation to land in the following passage:

There was no land law or tenure existing in the Colony at the time of its annexation to the Crown; and, in that condition of matters, the conclusion appears to their Lordships to be inevitable that, as soon as colonial land became the subject of settlement and commerce, all transactions in relation to it were governed by English law, in so far as that law could be justly and conveniently applied to them. ${ }^{74}$

Now if his Lordship had said that there was no land law or tenure suitable for application to the British settlers, this assertion would not have been as problematic. But clearly, in stating earlier in his judgment that the territory that became New South Wales was "without settled inhabitants or settled law," he meant that the Indigenous peoples had no law.

In this way, Lord Watson was able to conclude that New South Wales, and by implication the rest of Australia as well (New South Wales initially included all of the eastern half of Australia from the Pacific coast inland to the 135th meridian), was a settled colony in which English law applied automatically from the outset. However, reception of English law in a settled colony is limited to laws that are suitable for local conditions. William Blackstone, in a passage quoted by Lord Watson, put it this way:

... colonists carry with them only so much of the English law as is applicable to the condition of an infant Colony; such, for instance, as the general rules of inheritance and protection from personal injuries. The artificial requirements and distinctions incident to the property of a great and commercial people, the

\footnotetext{
${ }^{73}$ Cooper v Stuart, supra note 6 at 291.

${ }^{74}$ Ibid at 292.
} 
laws of police and revenue (such especially as are enforced by penalties), the mode of maintenance of the established Church, the jurisdiction of spiritual Courts, and a multitude of other provisions are neither necessary nor convenient for them, and therefore are not in force. ${ }^{75}$

The question, then, was whether the rule against perpetuities was suitable for the colony of New South Wales in 1823. The Privy Council decided that it was, given that it is "an important feature of the common law ... founded upon plain considerations of policy."76 However, this did not mean it applied to grants by the Crown. Assuming it applied to the Crown in England, Lord Watson said it would not necessarily follow that it applied in the colony. The main purpose for granting lands in New South Wales was to attract settlers, and it would have been impossible at the time to know what land might be required later for public purposes. The best way to ensure that land would be available for such purposes as the colony increased in population would be for the government to retain the right to resume portions of granted land indefinitely. For this reason, the Privy Council decided that the rule against perpetuities did not apply to the Crown in the colony and so the reservation of a right to resume ten acres was valid.

Even though it had nothing to do with Indigenous rights, Cooper $v$ Stuart became the leading authority on the status of Australia as settled and on the absence of Indigenous law. ${ }^{77}$ Although related, these are separate issues. The classification of a colony is a constitutional matter that

\footnotetext{
${ }^{75}$ William Blackstone, Commentaries on the Laws of England, 4 vols (Oxford: Clarendon Press, 1765-69), I, 107, quoted in Cooper v Stuart, supra note 6 at 291-92.

${ }^{76}$ Cooper $v$ Stuart, supra note 6 at 293.

${ }^{77}$ E.g. see $R v$ Wedge, [1976] 1 NSWLR 581 at 582-84; Coe $v$ Commonwealth of Australia, [1979] HCA 68, 53 ALJR 403 [Coe], Gibbs J at 408, cf Murphy J (dissenting) at 412. For discussion of other cases accepting, either explicitly or implicitly, these aspects of Cooper $v$ Stuart, see Mabo No 2, supra note 1 at 102-04 (Deane \& Gaudron JJ); Kent McNeil, "A Question of Title: Has the Common Law Been Misapplied to Dispossess the Aboriginals?" (1990) 16 Monash U L Rev 91 [McNeil, "A Question of Title"].
} 
determines, as we have seen, whether English or local law is in force. It also determines the prerogative powers of the Crown, as in conquered and ceded colonies (unlike settlements) the Crown has legislative authority until English law is introduced or a legislative assembly is promised or created. ${ }^{78}$ Classification of a colony as settled means that there was no sovereign recognized as such by the British Crown, but it does not follow that there was no local law prior to colonization. In Africa, the Gold Coast (Ghana) and Kenya are examples of settled colonies with acknowledged local systems of customary law. ${ }^{79}$ In Canada, British Columbia must have been settled because there was no conquest of or cession from the Indigenous peoples, and yet they had their own legal systems, which, although not respected by the Crown, were never entirely suppressed. ${ }^{80}$

When Lord Watson stated that New South Wales "was peacefully annexed to the British dominions" at a time when it was "practically unoccupied, without settled inhabitants or settled law," 81 he was clearly expressing factual findings that should have required supporting evidence. No such evidence is to be found in the trial judgment, in which Primary Judge Manning simply applied common law precedents without any mention of the condition of the Indigenous peoples or of how New South Wales had been acquired. Nor were these matters referred to by the justices of the New

\footnotetext{
78 Campbell v Hall (1774), Lofft 655 (98 ER 848), 1 Cowp 204 (98 ER 1045).

${ }^{79}$ See Angu v Attu (1916) Gold Coast PC Judgments 1874-1928, 23; Amissah v Krabah (1936) 2 WACA 30 (PC); Kimani v Gikanga (1965) EALR 735; Roberts-Wray, supra note 72 at 762, 765, 789, 791; AN Allott, "The Judicial Ascertainment of Customary Law in British Africa" (1957) 20 Modern L Rev 244. ${ }^{80}$ See Delgamuukw, supra note 3, especially paras 112,114; Tsilhqot'in Nation, supra note 4, especially paras 4, 35, 69; Valerie Ruth Napoleon, “Ayook: Gitksan Legal Order, Law, and Legal Theory”, PhD dissertation, Faculty of Law, University of Victoria, 2009, online: https://dspace.library.uvic.ca/bitstream/handle/1828/1392/napoleon\%20dissertation\%20April\%202609.pdf?sequence=1\&isAllowed=y; Borrows, Canada's Indigenous Constitution, supra note 29; Robert YELḰÁT¥E Clifford, "WSÁNEĆ ("The Emerging People”): Stories and the Re-Emergence of WSÁNEĆ Law”, in Karen Drake \& Brenda L Gunn, eds, Renewing Relationships: Indigenous Peoples and Canada (Saskatoon: University of Saskatchewan Native Law Centre, 2019), 83.

${ }^{81}$ Cooper $v$ Stuart, supra note 6 at 291 (my emphasis).
} 
South Wales Supreme Court on appeal. Lord Watson himself said "[t]here are no facts in dispute, $" 82$ and yet he reached factual conclusions that were certainly based on assumptions rather than evidence. Moreover, those assumptions were patently wrong. New South Wales was not acquired peacefully; on the contrary, violence against the Indigenous inhabitants was a common feature of the colonization process. In Coe $v$ Commonwealth of Australia, Murphy J (dissenting on other grounds) observed:

Although the Privy Council referred in Cooper v. Stuart to
peaceful annexation, the aborigines did not give up their lands
peacefully; they were killed or removed forcibly from the lands
by United Kingdom forces or the European colonists in what
amounted to attempted (and in Tasmania almost complete)
genocide. The statement by the Privy Council may be regarded
either as having been made in ignorance or as a convenient
falsehood to justify the taking of aborigines' land. ${ }^{83}$

Lord Watson's observation that New South Wales was "without settled inhabitants or settled law" was also incorrect. The Indigenous inhabitants were intimately connected to the land and had extensive knowledge of the geography and natural resources upon which they depended for their existence. ${ }^{84}$ They also had social and governance structures which, although vastly different from those in Europe, were suited

\footnotetext{
${ }^{82}$ Ibid at 289.

${ }^{83}$ Coe, supra note 77 at 138. See also Henry Reynolds, The Other Side of the Frontier: Aboriginal Resistance to the European Invasion of Australia (Ringwood; Harmondsworth: Penguin, 1982), and Forgotten War (Sydney: University of New South Wales Press, 2013); Richard Broome, "The Struggle for Australia: Aboriginal-European War, 1770-1930", in M McKernan \& M Browne, eds, Australia: Two Centuries of War and Peace (Canberra: Australian War Memorial in association with Allen \& Unwin, 1988), 92-120; Bain Attwood \& S.G. Foster, eds, Frontier Conflict: The Australian Experience (Canberra: National Museum of Australia, 2003); Bain Attwood, Telling the Truth about Aboriginal History (Crows Nest, NSW: Allen \& Unwin, 2005), especially 87-135.

${ }^{84}$ See Norman B Tindale, Aboriginal Tribes of Australia: Their Terrain, Environmental Controls, Distribution, Limits, and Proper Names (Berkeley: University of California Press, 1974), especially 55109; Fred Cahir, Ian D Clark \& Philp A Clarke, Aboriginal Biocultural Knowledge in South-eastern Australia: Perspectives of Early Colonists (Clayton South, VIC: CSIRO Publishing, 2018).
} 
to their worldviews and ways of life. ${ }^{85}$ Their relationships with one another and the lands, waters, animals, and plants were governed by complex systems of law that were no doubt not generally perceived by the British settlers, in part because these laws were not written down, but more significantly because in the Eurocentric and racist minds of most settlers the Indigenous peoples were too "primitive" to have laws. ${ }^{86}$ This view was evidently shared by the members of the Privy Council who decided Cooper v Stuart.

As we have seen, when the case was heard in the 1880s social evolution theorists generally ranked human societies on a scale ranging from savage through barbaric up to civilized. Proponents of this theory thought that societies tended to progress from the lower to the higher levels through a process similar to the evolution of species, with European societies naturally at the top. Lewis Henry Morgan, a prominent and influential proponent of social evolution theory, in his book, Ancient Society: or Researches in the Lines of Human Progress from Savagery Through Barbarism to Civilization, published in 1877, made this stark assessment: "The Australians rank below the Polynesians, and far below the American aborigines. They stand below the African negro and near the bottom of the scale. Their social institutions, therefore, must approach the primitive type as nearly as those of any existing people." ${ }^{, 87}$ As revealed in the St.

\footnotetext{
${ }^{85}$ See AW Howitt, The Native Tribes of South-East Australia (London: Macmillan \& Co, 1904, republished Canberra: Aboriginal Studies Press, 1996); Ronald M \& Catherine H Berndt, The World of the First Australians: Aboriginal Traditional Life, Past and Present, $5^{\text {th }}$ ed (Canberra: Aboriginal Studies Press, 1988).

${ }^{86}$ See Berndt, supra note 85 at 335-66; Heather McCrae et al, Indigenous Legal Issues: Commentary and Materials, 4th ed ((Pyrmont, NSW: Thomson Reuters, 2009), 65-133.

${ }^{87}$ Morgan, supra note 25 at 51. On possible explanations for Morgan's misinformed assessment of Indigenous society in Australia, see Georg Pfeffer, Lewis Henry Morgan's Comparisons: Reassessing Terminology, Anarchy and Worldview in Indigenous Societies of America, Australia and Highland Middle India (New York: Berghahn Books, 2019), 118-19. As Pfeffer explains, this assessment contrasted with
} 
Catherine's case, views of this kind seeped into judicial thinking and may well have influenced Lord Watson's assumption that Australia was "without settled inhabitants or settled law" when it became a British colony.

\section{The Modern Case Law}

(a) Australia

\section{(i) Milirrpum v Nabalco Pty}

The first Australian case to address the issue of Indigenous land rights directly was Milirrpum $v$ Nabalco Pty, ${ }^{88}$ decided by the Supreme Court of the Northern Territory in 1971. The action was brought by members of the Rirratjingu, Gumatj, and Djapu clans, for themselves and the other members thereof, to prevent the defendant company from mining bauxite on lands on the Gove Peninsula in the Northern Territory to which the plaintiffs claimed exclusive rights. As summarized by Justice Blackburn,

The plaintiffs' central contention was that at common law the rights, under native law or custom, of native communities to land within territory acquired by the Crown, provided that these rights were intelligible and capable of recognition by the common law, were rights which persisted, and must be respected by the Crown itself and by its colonizing subjects, unless and until they were validly terminated. ${ }^{89}$

\footnotetext{
Morgan's careful study of Haudenosaunee society that was based on actual observation. See Lewis H Morgan, League of the Ho-De'-No-Sau-Nee, or Iroquois (Rochester NY: Sage \& Brother, 1851). 88 (1971) 17 FLR 141 [Milirrpum]. For critical commentary, see John Hookey, "The Gove Land Rights Case: A Judicial Dispensation for the Taking of Aboriginal Lands in Australia?" [1972] 5 Fed L Rev 85; Geoffrey Lester \& Graham Parker, "Land Rights: The Australian Aborigines Have Lost a Legal Battle, But..." (1973) 11 Alberta L Rev 189; Barbara Hocking, "Does Aboriginal Law Now Run in Australia?" (1979) $10 \mathrm{Fed} L \mathrm{Rev} 161$. For discussion of earlier cases that implicitly denied the existence of these rights, see McNeil, "Question of Title", supra note 77.

${ }^{89}$ Milirrpum, supra note 88 at 149.
} 
The plaintiffs contended that their proprietary rights were still in existence and that these rights had been unlawfully invaded by Nabalco. They asked the court for declarations that they "are entitled to the occupation and enjoyment of the subject land free from interference"; that the Minerals (Acquisition) Ordinance 1953 was ultra vires and void to the extent that it purported to vest the bauxite and other minerals in the Crown; and that "the Commonwealth had no interest in the subject land enabling it effectively to grant any leases or other rights over it." 90 They also requested an injunction and damages.

The Commonwealth, as one of the defendants, contended that the 1953 Ordinance and the subsequent Mining (Gove Peninsula Nabalco Agreement) Ordinance 1968, which approved an agreement granting the mineral lease to Nabalco for the purpose of mining bauxite, were valid and consequently the lease was also valid. The defendant company relied on the lease to justify its presence and activities on the land.

Justice Blackburn said the following question of fact had to be decided: "what, in the plaintiffs' own eyes, is their relationship to the subject land?"91 Then there were questions of law. How could that relationship be proved? Does the common law contain a doctrine of native title as propounded by counsel for the plaintiffs? If it does, is the plaintiffs' relationship to the land such as to bring it within that doctrine? And what has been the legal effect of events and legislation since 1788 when New South Wales (which then, from the Crown's perspective, included the subject lands) was first settled by the British?

\footnotetext{
${ }^{90} \mathrm{Ibid}$ at $150-51$.

${ }^{91}$ Ibid at 151.
} 
After dealing with and dismissing the defendants' objections to the admissibility of the oral evidence of the clan members and the two anthropologists who testified as experts, Justice Blackburn assessed the evidence of the plaintiffs' way of life, including their social organization and laws relating to land. Helpfully, the defendants had agreed that, if

... the Court made findings of fact about the clan system and about the land-holding system in the period immediately before the establishment of the Mission [the Yirrkala Methodist Mission, the first permanent non-Aboriginal settlement on the subject lands, established in 1935], the defendants would admit that the systems of clan organization and of land holding had existed in 1788 and continuously thereafter, but this did not involve any admission that any particular clan had held any particular area of land since that time. ${ }^{92}$

Turning to the issue of the clans' relationship with the land, Blackburn $\mathrm{J}$ remarked that it is undoubtedly "a religious relationship," as "the physical and spiritual universes are not felt as distinct." 93 Considering all the evidence, he concluded that "the aboriginals do, as their counsel contended, think of the subject land as consisting of a number of tracts of land each linked to a clan, the total of which exhausts the subject land, though the boundaries between them are not precise in the sense in which boundaries are understood in our law." 94

This factual conclusion did not, however, lead Justice Blackburn to conclude that the clans have a legal right to the subject land at common law. Relying on Re Southern Rhodesia,${ }^{95}$ he stated that their rights under their own laws and customs would have to be proprietary in order to give rise to

\footnotetext{
92 Ibid at 153 (Blackburn J's emphasis).

${ }^{93}$ Ibid at 167.

${ }^{94}$ Ibid at 179 .

${ }^{95}$ Supra note 59 at 232-33.
} 
common law land rights. ${ }^{96}$ The problem was not that the clans lacked discernible laws and customs in relation to land. On the contrary, Blackburn J said:

The evidence shows a subtle and elaborate system highly adapted to the country in which the people led their lives, which provided a stable order of society and was remarkably free from the vagaries of personal whim or influence. If ever a system could be called "a government of laws and not of men", it is that shown in the evidence before me. ${ }^{97}$

Instead, the hurdle the plaintiffs were unable to overcome was convincing him that their laws give them rights that are proprietary in nature. He observed:

The evidence seems to me to show that the aboriginals have a more cogent feeling of obligation to the land than of ownership of it. It is dangerous to attempt to express a matter so subtle and difficult by a mere aphorism, but it seems easier, on the evidence, to say that the clan belongs to the land than that the land belongs to the clan. ${ }^{98}$

One can criticize Justice Blackburn's legal conclusion that the clans' relationship with the land was not proprietary for being too dependent on English law criteria, such as the right to alienate and the right to exclude others from the land. ${ }^{99}$ Nevertheless, he also denied the plaintiffs' claim as a matter of law by questionable interpretation of the jurisprudence from Africa, India, New Zealand, and the United States, ${ }^{100}$ which led him to conclude that there is no common law doctrine of communal native title. So

\footnotetext{
${ }^{96}$ Milirrpum, supra note 88 at 264.

${ }^{97}$ Ibid at 267.

${ }^{98}$ Ibid at 270-71. The plaintiffs were also unable to convince Blackburn J, "on the balance of probabilities, that the plaintiffs' predecessors had in 1788 the same links to the same area of land as those which the plaintiffs now claim": ibid at 198.

${ }^{99}$ See ibid at 272.

${ }^{100} \mathrm{Ibid}$ at 209-18, 223-42. See Hookey, supra note 88. Blackburn J also held that, if the plaintiffs ever had communal native title to the minerals on the subject lands, it had been legislatively extinguished by the Minerals (Acquisition) Ordinance 1953 and the Mining (Gove Peninsula Nabalco Agreement) Ordinance 1968: Milirrpum, supra note 88 at 283-92.
} 
regardless of the extensive evidence of the plaintiffs' laws and land use, their case was bound to fail on Blackburn J's understanding of the law.

In concluding that the plaintiffs did not have land rights to which the common law could give effect, Justice Blackburn also relied on Lord Watson's judgments in the St. Catherine's case and Cooper $v$ Stuart. ${ }^{101} \mathrm{We}$ have seen that, in the former case, Lord Watson based his decision that the only source of Indigenous land rights in Canada is the Royal Proclamation of 1763 on Chancellor Boyd's prejudiced assumptions rather than on actual facts. In Cooper v Stuart, there was no evidence at all for Lord Watson's conclusion that New South Wales was "without settled inhabitants or settled law, at the time when it was peacefully annexed to the British dominions."102 Nonetheless, Blackburn $\mathrm{J}$ thought he was bound by the ruling in that case that New South Wales was a settled colony because the classification of a colony as conquered and ceded or settled is a matter of law. ${ }^{103}$ The problem here is that, even if one admits that the classification is a matter of law, it must have a factual basis. Lord Watson concluded that New South Wales was settled because he made an erroneous assumption of fact, namely that the territory was "without settled inhabitants or settled law." When the factual basis for a legal conclusion is shown to be false, the conclusion is undercut and should no longer be regarded as having precedential value. As respected English jurist Herbert Broom succinctly put it, "[i]f the fact be perverted or misrepresented the law which arises thence will unavoidably be

\footnotetext{
${ }^{101}$ Milirrpum, supra note 88 at 218-19, 242-44, 249, 263. Blackburn J also relied at 219-23 on the decisions denying the existence of Aboriginal title at trial and in the British Columbia Court of Appeal in Calder v Attorney-General of British Columbia (1969) 8 DLR (3d) 59, (1970) 13 DLR 64, decisions that were subsequently overturned on this issue by the Supreme Court of Canada, [1973] SCR 313.

102 Cooper v Stuart, supra note 6 at 291.

${ }^{103}$ Milirrpum, supra note 88 at 242, 249.
} 
unjust or partial." 104 However, it was no doubt too late in 1971 to change the classification of New South Wales to conquered, as it had been assumed since 1788 that English law had been received at that time because the colony was settled. ${ }^{105}$ Nonetheless, if Blackburn J had viewed the plaintiffs' relationship with the land as proprietary, he could have decided that the reception of English law did not obliterate their land rights under their own laws and customs, without reclassifying New South Wales. ${ }^{106}$ This would have entailed rejection of Lord Watson's erroneous assumption - which, from a common law perspective, ${ }^{107}$ was clearly a matter of fact rather than of law - that "[t]here was no land law or tenure existing in the colony at the time of its annexation to the Crown."108 While acknowledging that Lord Watson's assumption was mistaken, Blackburn $\mathbf{J}$ nonetheless ruled that English law, including real property law, applied throughout New South Wales from 1788 on, even on the far-off Gove Peninsula where no English person settled until 1935, and then only missionaries arrived. Included was the doctrine of tenure, the effect of which he described in stark terms:

... the Crown is the source of title to all land; ... no subject can own land allodially, but only an estate or interest in it which he holds mediately or immediately of the Crown. On the foundation of New South Wales, therefore, every square inch of territory in the colony became the property of the Crown. All titles, rights, and interests whatever in land which existed thereafter in subjects of the Crown were the direct consequence of some grant from the Crown. The plaintiffs, who cannot point

\footnotetext{
${ }^{104}$ Herbert Broom, A Selection of Legal Maxims; Classified and Illustrated, 7th ed by Herbert F Manisty \& Herbert Chitty (London: Sweet and Maxwell, 1900), 80. Broom relied on the legal maxim ex facto jus oritur (the law arises out of the fact).

${ }^{105}$ See Coe, supra note 77.

${ }^{106}$ This would be the conclusion reached 21 years later by the High Court in Mabo No 2, supra note 1, discussed below, which also effectively overruled Blackburn J's decision regarding the non-proprietary nature of Indigenous land rights in Australia.

${ }^{107}$ At common law, the existence of Indigenous law prior to Crown acquisition of sovereignty would be a factual matter to be established by evidence: see Mabo No 2, supra note 1 at 59 .

${ }^{108}$ Cooper v Stuart, supra note 6 at 292.
} 
to any grant from the Crown as the basis of the title which they claim, cannot succeed unless they can show there is a doctrine in their favour which in Australia co-exists in some manner with the dominion of the Crown. ${ }^{109}$

Since the plaintiffs were unable to convince Justice Blackburn that their relationship with the land was proprietary or that the common law contains a doctrine of communal native title, they lost their case despite the evidence in their favour. The Milirrpum decision was not appealed, and another 20 years would pass before the issue of the existence of Indigenous land rights reached the High Court of Australia in Mabov Queensland [No 2]. ${ }^{110}$

\section{(ii) Mabo No 2}

The Mabo No 2 litigation was commenced directly in the High Court in 1982 by Eddie Mabo, Celuia Mapo Salee, Sam Passi, David Passi, and James Rice, members of the Meriam People who occupy the Murray Islands in the Torres Strait off the northern tip of mainland Queensland. ${ }^{111}$ The High Court thus had jurisdiction over both the factual and legal issues,

\footnotetext{
${ }^{109}$ Milirrpum, supra note 88 at 245. In reality, the notion that all land titles originate from Crown grants is a legal fiction created to provide a basis for the Crown's underlying title in England: see McNeil, Common Law Aboriginal Title, supra note 38, ch 3. For a case holding that land rights based on possession are valid against the Crown, see Perry v Clissold, supra note 39, affirming the decision of the High Court of Australia, (1904) 1 CLR 363.

${ }^{110}$ Mabo No 2, supra note 1. The literature on the case is extensive: e.g. see Richard Bartlett, "The Aboriginal Land Which May Be Claimed at Common Law: Implications of Mabo" (1992) 22 UWA L Rev 272; Essays on the Mabo Decision (Sydney: Law Book Co, 1993); MA Stephenson \& Suri Ratnapala, eds, Mabo: A Judicial Revolution. The Aboriginal Land Rights Decision and Its Impact on Australian Law (St Lucia, Qld: University of Queensland Press, 1993); Murray Goot \& Tim Rouse, eds, Make Us a Better Offer: The Politics of Mabo (Leichhardt, NSW: Pluto Press Australia, 1994); Jeremy Webber, "The Jurisprudence of Regret: The Search for Standards of Justice in Mabo" (1995) 17 Sydney L Rev 5; Peter H Russell, Recognizing Aboriginal Title: The Mabo Case and Indigenous Resistance to English-Settler Colonialism (Toronto: University of Toronto Press, 2005); Bryan Keon-Cohen, Mabo in the Courts, Islander Tradition to Native Title: A Memoir, 2 vols (North Melbourne: Chancery Bold, 2011); Toni Bauman \& Lydia Glick, eds, The Limits of Change: Mabo and Native Title 20 Years On (Canberra: Australian Institute of Aboriginal and Torres Strait Islanders Studies, 2012).

${ }^{111}$ See Keon-Cohen, supra note 110, vol I, 70-72.
} 
though instead of conducting a trial itself it remitted the fact-finding role to Justice Moynihan of the Supreme Court of Queensland.

The islands in the Torres Strait had been annexed to the Colony of Queensland in 1879 pursuant to Letters Patent issued by Queen Victoria. The plaintiffs alleged that acquisition of sovereignty by the Crown, which they did not challenge, did not impair the pre-existing land rights of the Murray Islanders based on their traditional laws and customs. In 1985, the Queensland Parliament passed the Queensland Coast Islands Declaratory Act 1985 (Q), an unabashed attempt to stop the litigation in its tracks by declaring that all the lands on the Torres Strait Islands became vested in the Crown at the moment the islands were annexed in $1879 .{ }^{112}$ That enactment resulted in Mabo v Queensland [No 1], ${ }^{113}$ in which the High Court decided that the statute conflicted with Racial Discrimination Act 1975 (Cth) because it discriminated against the Islanders on the basis of race and so was invalid. ${ }^{114}$ That decision meant that the plaintiffs' case could proceed.

In 1989, Justice Moynihan delivered his factual findings to the High Court, which then proceeded to decide the case on the basis of these findings and the applicable law. The factual findings, which comprise 229 typescript pages, provided detailed information on the people of the Murray Islands and their society, culture, and relationship with the land. ${ }^{115}$ The evidence revealed that there was no public or common land on the Murray Islands, as

\footnotetext{
${ }^{112}$ See ibid, vol I, 113-20.

113 (1989) 166 CLR 186.

${ }^{114}$ See Keon-Cohen, supra note 110, vol I, 205-45; Greg McIntyre, “Aboriginal Title: Equal Rights and Racial Discrimination" (1993) 16 UNSWLJ 157; Kent McNeil, "Racial Discrimination and Unilateral Extinguishment of Native Title" (1996) 1 Australian Indigenous Law Reporter 181, reprinted in Kent McNeil, Emerging Justice? Essays on Indigenous Rights in Canada and Australia (Saskatoon: University of Saskatchewan Native Law Centre, 2001), 357.

${ }^{115}$ Determination Pursuant to Reference of 27 February 1986, by the High Court of Australia to the Supreme Court of Queensland to hear and determine all issues of fact raised by the pleadings, particulars and further particulars in High Court Action B12 of 1892 [Moynihan J's Determination].
} 
all the land belonged either to individuals or groups. ${ }^{116}$ While unable to make findings regarding the precise details of the landholding laws and customs of the Meriam People, Justice Moynihan was nonetheless able to conclude from the evidence that the Islanders had land rights under their own legal system. In the High Court, Justice Brennan, delivering the main judgment, ${ }^{117}$ stated:

Whatever be the precision of Meriam laws and customs with respect to land, there is abundant evidence that land was traditionally occupied by individuals or family groups and that contemporary rights and interests are capable of being established with sufficient precision to attract declaratory or other relief. Although the findings made by Moynihan J. do not permit a confident conclusion that, in 1879 , there were parcels of land in the Murray Islands owned allodially by individuals or groups, the absence of such a finding is not critical to the final resolution of this case. ${ }^{118}$

It was then up to the High Court to decide whether, as a matter of law, those rights and interests survived the Crown's acquisition of sovereignty. ${ }^{119}$ All the judges except Dawson $\mathbf{J}$ were of the opinion that they not only survived but also continued until validly extinguished by the Crown. ${ }^{120}$ In so deciding, the Court distinguished between acquisition of sovereignty and

\footnotetext{
${ }^{116} \mathrm{Ibid}$, ch 9 at 17; Mabo No 2, supra note 1 at 22.

117 Brennan J's judgment was concurred in by Mason CJ and McHugh J, Mabo No 2, supra note 1 at 15-16. Deane and Gaudron JJ delivered a concurring judgment differing from Brennan J's in some particulars, as did the concurring judgment of Toohey J. Dawson J dissented, as in his opinion native title is not a legal entitlement but amounts to mere permissive occupation of Crown land.

${ }^{118} \mathrm{Ibid}$ at 63, and see 75-76. See also Deane and Gaudron JJ at 115-16, Toohey J at 190-92.

119 At the end of Moynihan J's Determination, supra note 115, ch 11 at 75, he expressed some frustration with the process that had separated his fact-finding role from the High Court's determination of the legal issues. He stated: "As I understand, and have experienced it, the role of a Judge at first instance is to determine the issues of fact and law in the action - and hence the action. They seem to me inextricably interwoven. The experience has been unsatisfying because it seems to me that is the very thing the terms of the remitter have prevented me from doing."

${ }^{120}$ The Court decided that, apart from leasehold parcels and lands validly appropriated for administrative purposes, the Meriam People's native title had not been extinguished: Mabo No 2, supra note 1 at 76, 217.
} 
acquisition of land. ${ }^{121}$ While not overruling the Privy Council's decision in Cooper v Stuart that Australia was a settled colony, the majority concluded that acquisition of sovereignty did not necessarily entail acquisition of title to land, aside from the Crown's radical or underlying title that supports the doctrine of tenure "which could not be overturned without fracturing the skeleton which gives our land law its shape and consistency." ${ }^{122}$ Referring to Lord Watson's dictum in Cooper v Stuart that New South Wales was "without settled inhabitants or settled law," Brennan J said it was an "assumption that proved false," as revealed by the evidence in the Milirrpum case:

The facts as we know them today do not fit the "absence of law" or "barbarian" theory underpinning the colonial reception of the common law of England.... The theory that the Indigenous inhabitants of a "settled" colony had no proprietary interest in the land thus depended on a discriminatory denigration of indigenous inhabitants, their social organization and customs. ${ }^{123}$

In a clear rejection of the kinds of attitudes towards Indigenous peoples revealed in the St. Catherine's case and Cooper $v$ Stuart and of the social evolution mindset expressed in Re Southern Rhodesia, Brennan J added that "doctrines of the common law which depend on the notion that native peoples may be 'so low in the scale of social organization' that it is 'idle to impute to such people some shadow of the rights known to our law' can hardly be retained... [I]t is imperative in today's world that the common

\footnotetext{
${ }^{121} \mathrm{Ibid}$, Brennan $\mathrm{J}$ at 43-45.

122 Ibid, Brennan $\mathrm{J}$ at 45.

${ }^{123}$ Ibid at 39-40.
} 
law should neither be nor be seen to be frozen in an age of racial discrimination." 124

Justice Brennan seems to have thought it would require a change in the common law for the pre-existing land rights of the Indigenous inhabitants of settled territories to be acknowledged. ${ }^{125}$ But this was not so. Milirrpum did have to be overruled, it is true, but that was only a trial court decision where Justice Blackburn felt bound by Cooper $v$ Stuart insofar as the classification of New South Wales as settled was concerned. But Cooper $v$ Stuart had nothing to do with Indigenous land rights and erroneously assumed, as Brennan J pointed out, that Indigenous Australians had no law. If, as in Mabo No 2, the factual basis for pre-existing land rights had been established in a case that went to the Privy Council, it is not at all apparent that their Lordships would have denied the existence of those rights. On the contrary, we have seen that in appeals from the Isle of Man, British Honduras, Southern Rhodesia, Nigeria, and New Zealand, both before and after Cooper $v$ Stuart, the Privy Council envisaged, and in some cases accepted, the existence of Indigenous land rights based on occupation of lands in accordance with Indigenous law and custom. ${ }^{126}$ Nor was the continuation of land rights in those cases determined by the distinction between settled and conquered or ceded colonies. What was different was that in the latter class of colonies the pre-existence of law was a given because the colony had been acquired from another sovereign, whereas in settled colonies it was assumed that there was no law because, from the British perspective, there was no sovereign. Evidence of pre-existing laws

\footnotetext{
${ }^{124}$ Ibid at 41-42, quoting from Re Southern Rhodesia, supra note 59 at 233-34. See also per Deane and Gaudron JJ at 104, 108-09.

${ }^{125}$ Ibid at 39-42.

${ }^{126}$ See text accompanying notes $46-69$, above.
} 
was therefore required, but it was not presented in Cooper $v$ Stuart because the case involved the application of the rule against perpetuities to a Crown grant, not Indigenous land rights. By way of contrast, in Mabo No 2 extensive evidence of the laws and customs of the Murray Islanders was received by Justice Moynihan and transmitted to the High Court, revealing that they had pre-existing land rights under their own laws at the time the Crown asserted sovereignty in $1879 .{ }^{127}$ This evidence provided the Court with the factual basis to issue a declaration acknowledging the Islanders' rights "as against the whole world to possession, occupation, use and enjoyment of the lands of the Murray Islands." 128

\section{(a) Canada}

Lord Watson's dicta in the St. Catherine's case that Aboriginal title is "a personal and usufructuary right" derived from the Royal Proclamation of

\footnotetext{
${ }^{127}$ SEK Hulme argued in "Aspects of the High Court's Handling of Mabo" (1993) 87 Vict Bar News 29 that the Court should not have used a case involving unique facts pertaining to the Murray Islanders to generalize regarding Indigenous land rights elsewhere in Australia. Compare Ron Castan \& Bryan KeonCohen (barristers for the plaintiffs in the Mabo case), "Mabo and the High Court: A Reply to SEK Hulme, Q.C." (1993) 87 Vict Bar News 47. Contrary to Hulme's view, what the Court did in Mabo was establish the common law principles on which claims to native title depend and then apply those principles to the facts as found by Moynihan J. Other native title cases likewise depend on proof of facts relative to the specific Indigenous people claiming the title: e.g. see Commonwealth v Yarmirr (2001) 208 CLR 1 [Yarmirr]; Western Australia $v$ Ward (2002) 213 CLR 1 [Ward]; Members of the Yorta Yorta Aboriginal Community v Victoria (2002) 214 CLR 422 [Yorta Yorta]; Akiba v Commonwealth (2013) 250 CLR 209 [Akiba]. See generally Lisa Strelein, Compromised Jurisprudence: Native Title Cases Since Mabo, $2^{\text {nd }}$ ed (Canberra: Aboriginal Studies Press, 2009); Richard Bartlett, Native Title in Australia, $4^{\text {th }}$ ed (Chatswood, NSW: LexisNexis, 2019).

${ }^{128}$ High Court Order, Mabo No 2, supra note 1 at 217. Note that this declaration may not appear to be consistent with the Court's acceptance of Moynihan J's finding that there was "no concept of public or general community ownership among the people of Murray Island" (ibid at 22), if "Native title has its origin in and is given its content by the traditional laws acknowledged and the traditional customs observed by the indigenous inhabitants of a territory" (ibid at 58). However, in my opinion the better view is that Brennan J regarded the totality of the evidence of the Meriam People's occupation and use of the Murray Islands and of their laws and customs that governed their relationship with the land as giving rise to a communal title good against the whole world: see ibid at 51-52, 61-62, and quotation accompanying note 118 above. But this was not the interpretation of his judgment that was incorporated into the Native Title Act 1993 (Cth), s 223(1): see Kent McNeil, "Mabo Misinterpreted: The Unfortunate Legacy of Legislative Distortion of Justice Brennan's Judgment", in Bauman \& Glick, supra note 110 at 226.
} 
1763, and a mere burden on the Crown's "substantial and paramount" proprietary estate, ${ }^{129}$ informed legal and political perceptions of Indigenous land rights in Canada up until (and even after) the Supreme Court of Canada's 1973 decision in Calder $v$ Attorney-General of British Columbia. ${ }^{130}$

\section{(i) Calder v Attorney-General of British Columbia}

In Calder, the Nisga'a Nation (spelled Nishga in the judgments) sought a declaration that their Aboriginal title to lands in north-western British Columbia had never been lawfully extinguished. Although the majority of the Supreme Court dismissed the action on a technical procedural point, ${ }^{131}$ six of the seven judges decided that Aboriginal title existed as a legal right in British Columbia, though three thought it had been legislatively extinguished prior to the entry of the province into Canada in $1871 .{ }^{132}$

\footnotetext{
${ }^{129}$ St. Catherine's, supra note 5 at 54, 55, 58.

${ }^{130}$ Calder, supra note 2. For judicial confirmation of this aspect of Lord Watson's decision, see, for example, Attorney-General for Canada v Giroux (1916), 53 SCR 172 at 197; Attorney-General for Quebec $v$ Attorney-General for Canada, [1921] 1 AC 401 (PC) at 406, 409-10; $R v$ McMaster, [1926] Ex CR 68 at 73; St. Ann's Shooting and Fish Club Ltd v The King, [1950] SCR 211 at 219; Warman v Francis (1958) 20 DLR (2d) 627 (NBQB) at 634-35. In Isaac v Davey (1975), 5 OR 610 at 620, aff'd on other grounds [1977] 2 SCR 897, Arnup JA, for the Ontario Court of Appeal, found Chancellor Boyd's trial decision "to be of great assistance" and said Lord Watson's description of Indian title in Ontario "has been followed ever since." See also Smith v The Queen, [1983] 1 SCR 554 at 561, 568-69; Ontario (Attorney-General) v Bear Island Foundation (1984), 49 OR (2d) 353 (Ont SC) at 380-85, affirmed on other grounds, (1989) 68 OR (2d) 394 (Ont CA), [1991] 2 SCR 570. On the Canadian government's understanding of Aboriginal title before Calder, see Statement of the Government of Canada on Indian Policy (The White Paper, 1969), https://www.aadnc-aandc.gc.ca/eng/1100100010189/1100100010191\#chp13: "aboriginal claims to land ... are so general and undefined it is not realistic to think of them as specific claims capable of remedy except through a policy and program that will end injustice to Indians as members of the Canadian community."

${ }^{131}$ The plaintiffs did not get a fiat from the lieutenant-governor authorizing them to sue the Crown in right of the province, and so Pigeon J (Judson, Martland, and Ritchie JJ concurring on this issue) held that the courts did not have jurisdiction to decide the case.

132 Judson, Martland, and Ritchie JJ, whereas Hall, Spence, and Laskin JJ were of the view that it had not been extinguished. Delgamuukw, supra note 3, and Tsilhqot'in Nation, supra note 4, reveal that Hall, Spence, and Laskin JJ were right about this. In $R v$ Sparrow, [1990] 1 SCR 1075 at para 37, the Supreme Court adopted their test for extinguishment, namely "that the Sovereign's intention must be clear and plain if it is to extinguish an aboriginal right." The clear and plain test for extinguishment was also adopted by the High Court in Mabo No 2, supra note 1 at 64.
} 
Referring to Lord Watson's decision in St. Catherine's, Justice Judson observed that " $[\mathrm{t}]$ here can be no doubt that the Privy Council found that the Proclamation of 1763 was the origin of the Indian title," but this did not mean it was the title's "exclusive source."133 In his view, the Proclamation has never applied in British Columbia because the province has its own history and is outside that document's geographical limits. Nonetheless, in an oft-cited passage he regarded it to be clear that, although

... Indian title in British Columbia cannot owe its origin to the Proclamation of 1763, the fact is that when the settlers came, the Indians were there, organized in societies and occupying the land as their forefathers had done for centuries. This is what Indian title means and it does not help one in the solution of this problem to call it a "personal or usufructuary right". What they are asserting in this action is that they had a right to continue to live on their lands as their forefathers had lived and that this right has never been lawfully extinguished. ${ }^{134}$

Judson J's judgment thus undercut Lord Watson's decision on both the source and the nature of Aboriginal title. While not elaborating on the nature of the title because he thought it had been extinguished, Judson $\mathbf{J}$ clearly regarded occupation of land by organized Indigenous societies as its source.

Justice Hall disagreed with Judson $\mathbf{J}$ on the application of the Royal Proclamation - for him, it followed the flag as England extended its jurisdiction westward across the continent. ${ }^{135}$ But like Justice Judson, he did not regard it as the source of Aboriginal title in British Columbia; instead, it was declaratory of land rights that already existed. So what was the source of these rights? Hall $\mathrm{J}$ identified two sources: the common law and

\footnotetext{
${ }^{133}$ Calder, supra note 2 at 322.

134 Ibid at 328.

135 Ibid at 395.
} 
Indigenous law. Regarding the first source, he observed that "[p]ossession is of itself at common law proof of ownership... Unchallenged possession is admitted here."136 On the second source, he reviewed testimony from the trial about Nisga'a land laws and concluded: "What emerges from the foregoing evidence is the following: the Nishgas in fact are and were from time immemorial a distinctive cultural entity with concepts of ownership indigenous to their culture and capable of articulation under the common law."137 Whether based on possession or on Indigenous concepts of ownership, Aboriginal title thus has a factual basis: it depends on proof (or admission) of occupation of land or of Indigenous law: "Unlike the method used to make out title in other contexts," Hall $\mathbf{J}$ said, "proof of the Indian title or interest is to be made out as a matter of fact."138

It is in this regard that St. Catherine's and Calder differ: in the former case, there was no admission or evidence of Indigenous occupation or law, whereas in the latter there was. This permitted both Judson $\mathbf{J}$ and Hall $\mathbf{J}$ to distinguish Lord Watson's judgment and decide that the Royal Proclamation of 1763 is not the source of Indigenous land rights. But this also meant that the content of these rights does not depend on interpretation of the

\footnotetext{
${ }^{136} \mathrm{Ibid}$ at 368; see also 375. As authority, he cited two leading English textbooks, GC Cheshire, The Modern Law of Real Property, 10th ed (London: Butterworths, 1967), 659, and Robert Megarry \& HWR Wade, The Law of Real Property, 3d ed (London: Stevens, 1966), 999. For detailed discussion of possession as a source of Indigenous land rights, see McNeil, Common Law Aboriginal Title, supra note 38, especially ch 7.

${ }^{137}$ Calder, supra note 2 at 375.

${ }^{138} \mathrm{Ibid}$ at 354, relying on Amodi Tijani, supra note 63. This is not a denial that Indigenous law is actually law: see John Borrows, "Creating an Indigenous Legal Community" (2005) 50 McGill LJ 153 at 173, cited with approval by LeBel J in $R v$ Marshall; $R v$ Bernard, [2005] 2 SCR 220 at para 130 [Marshall/Bernard]. It is simply an acknowledgement that Indigenous law is generally outside the knowledge of Canadian judges and so, like foreign law, has to be revealed to them through evidence. On use of the same analogy in relation to customary law in British Africa, see Allott, supra note 79 at 246-48. On proof of foreign law, see Richard Fentiman, Foreign Law in English Courts: Pleadings, Proof and Choice of Law (Oxford: Oxford University Press, 1998); Colin Tapper, Cross and Tapper on Evidence, 12 ed (Oxford: Oxford University Press, 2010), 691-92; Hodge M Malek, ed, Phipson on Evidence, $19^{\text {th }}$ ed (London: Thomson Reuters, 1918), § 33-76, 33-77.
} 
Proclamation. For this reason, the Supreme Court, in the next important Aboriginal title case, Delgamuukw v British Columbia,${ }^{139}$ was able to depart from Lord Watson's characterization of Aboriginal title as "a personal and usufructuary right" and, subject to a couple of limitations, ${ }^{140}$ define it in terms very close to full ownership.

\section{(i) Delgamuukw v British Columbia}

The Delgamuukw case involved claims by the Gitxsan (spelled Gitksan in the judgments) and Wet'suwet'en Nations to Aboriginal title and self-government over their traditional territories in north-central British Columbia. ${ }^{141}$ The Supreme Court sent the case back to trial for the existence of Aboriginal title to be determined in accordance with the guidelines the Court laid down and for the self-government issue to be addressed in more detail (the case has not been retried). ${ }^{142}$ Chief Justice Lamer wrote the judgment, with McLachlin J (as she then was) concurring and La Forest and L'Heureux-Dubé JJ concurring in the result but offering separate reasons.

The parts of the Chief Justice's judgment that are relevant here deal with the interrelated issues of the source and content of Aboriginal title. Regarding source, he stated:

\footnotetext{
${ }^{139}$ Delgaтииkw, supra note 3. The Supreme Court also discussed the sources and content of Aboriginal title in Guerin, supra note 2, but that case involved reserve lands.

${ }^{140}$ See infra notes 153 and 170 , and accompanying text.

${ }^{141}$ Note that, in Canada, Aboriginal title, which is a "right to the land itself" (Delgamuukw, supra note 3 at para 138), is treated differently from other Aboriginal rights, such as hunting and fishing rights: see $R v$ Van der Peet [1996] 2 SCR 507; $R$ v Adams [1996] 3 SCC 101; $R v$ Côté [1996] 3 SCR 139. The situation in Australia is different, as all Indigenous rights in relation to land and waters are native title rights: e.g. see Yanner v Eaton (1999) 201 CLR 351; Yarmirr, supra note 127; Akiba, supra note 127. For discussion, see Kent McNeil, “Aboriginal Title and Aboriginal Rights: What's the Connection?" (1997) 36 Alberta L Rev 117.

${ }^{142}$ The Court declined to decide the case on the merits because the trial judge had not given the oral histories sufficient credence and weight and there was a defect in the pleadings.
} 
It had originally been thought that the source of aboriginal title in Canada was the Royal Proclamation, 1763: see St. Catherine's Milling. However, it is now clear that although aboriginal title was recognized by the Proclamation, it arises from the prior occupation of Canada by aboriginal peoples. That prior occupation, however, is relevant in two different ways, both of which illustrate the sui generis nature of aboriginal title. The first is the physical fact of occupation, which derives from the common law principle that occupation is proof of possession in law. Thus, in Guerin, $\left[{ }^{143}\right] \ldots$ Dickson J. described aboriginal title, at p. 376, as a "legal right derived from the Indians' historic occupation and possession of their tribal lands". What makes aboriginal title sui generis is that it arises from possession before the assertion of British sovereignty, whereas normal estates, like fee simple, arise afterward.... This idea has been further developed in Roberts $v$. Canada, [1989] 1 S.C.R. 322, where this Court unanimously held at p. 340 that "aboriginal title pre-dated colonization by the British and survived British claims of sovereignty" (also see Guerin, at p. 378). What this suggests is a second source for aboriginal title - the relationship between common law and preexisting systems of aboriginal law. ${ }^{144}$

In this important passage, Lamer $\mathrm{CJ}$ confirmed (without citing in this context) Justice Hall's view in Calder that Indigenous land rights have two interrelated sources, namely the common law and Indigenous law. ${ }^{145}$ However, neither of these judges made the relationship between these two systems of law clear. Elsewhere in his judgment, Lamer CJ suggested that

\footnotetext{
${ }^{143}$ Supra note 2.

${ }^{144}$ Delgamuukw, supra note 3 at para 114.

${ }^{145}$ Contrast this with the source of native title in Australia, which is pre-existing Indigenous custom and law that gives rise to rights that the common law recognizes: see Mabo No 2, supra note 1, especially per Brennan J at 58. This source was given legislative force by the Native Title Act 1993 (Cth), s 223(1): see Yanner v Eaton, supra note 141; Yarmirr, supra note 127; Ward, supra note 127; Yorta Yorta, supra note 127. For criticism, see Maureen Tehan, "A Hope Disillusioned, an Opportunity Lost? Reflections on Common Law Native Title and Ten Years of the Native Title Act" (2003) 27 Mel U L Rev 523; McNeil, "Mabo Misinterpreted", supra note 128; Young, The Trouble with Tradition, supra note 58 at 267-348.
} 
Indigenous law has a role in proving the exclusive occupation of land giving rise to title at the time of Crown assertion of sovereignty:

... the aboriginal group asserting the claim to aboriginal title may have trespass laws which are proof of exclusive occupation, such that the presence of trespassers does not count as evidence against exclusivity. As well, aboriginal laws under which permission may be granted to other aboriginal groups to use or reside even temporarily on land would reinforce the finding of exclusive occupation. ${ }^{146}$

He also said that "if, at the time of sovereignty, an aboriginal society had laws in relation to land, those laws would be relevant to establishing the occupation of lands which are the subject of a claim for aboriginal title. Relevant laws might include, but are not limited to, a land tenure system or laws governing land use."147 From these passages, it would seem that Indigenous law is not an independent source of Aboriginal title in Canada, but just part of the evidence that can be used to prove the exclusive occupation necessary to give rise to the title at common law. This interpretation might be reinforced by Lamer CJ's statement that "the source of aboriginal title appears to be grounded both in the common law and in the aboriginal perspective on land; the latter includes, but is not limited to, their systems of law. It follows that both should be taken into account in establishing the proof of occupancy."148

However, in deciding that "the relationship between common law and pre-existing systems of aboriginal law" is a second source of Aboriginal title, Chief Justice Lamer relied on Roberts $v$ Canada, where a unanimous Supreme Court held that "aboriginal title pre-dated colonization by the

\footnotetext{
${ }^{146}$ Delgamuukw, supra note 3 at para 157.

${ }^{147}$ Ibid at para 148.

${ }^{148}$ Ibid at para 147.
} 
British and survived British claims of sovereignty."149 This suggests reliance on the doctrine of continuity, whereby pre-existing rights are maintained and become enforceable in common law courts after sovereignty is acquired by the Crown. ${ }^{150}$ He said as well that Aboriginal title "is also sui generis in the sense that its characteristics cannot be completely explained by reference either to the common law rules of real property or to the rules of property found in aboriginal legal systems. As with other aboriginal rights, it must be understood by reference to both common law and aboriginal perspectives." And yet, when it came to describing the content of Aboriginal title, he did so in a generic way that would apply equally to Aboriginal titleholders across Canada, regardless of their own laws that can vary greatly from one Indigenous nation to another. ${ }^{152}$ He said this:

... the content of aboriginal title can be summarized by two propositions: first, that aboriginal title encompasses the right to exclusive use and occupation of the land held pursuant to that title for a variety of purposes, which need not be aspects of those aboriginal practices, customs and traditions which are integral to distinctive aboriginal cultures; and second, that those protected uses must not be irreconcilable with the nature of the group's attachment to that land. ${ }^{153}$

\footnotetext{
${ }^{149}$ Roberts v. Canada [1989] 1 SCR 322 at 340, quoted in Delgamuukw, supra note 3 at para 114.

${ }^{150}$ See supra note 65 and accompanying text.

${ }^{151}$ Delgamuukw, supra note 3 at para 112.

${ }^{152}$ See Brian Slattery, "A Taxonomy of Aboriginal Rights", in Hamar Foster, Heather Raven \& Jeremy Webber, eds, Let Right Be Done: Aboriginal Title, the Calder Case, and the Future of Indigenous Rights (Vancouver: UBC Press, 2007), 111, especially at 118. On Indigenous legal systems, see James Youngblood Henderson, First Nations Jurisprudence and Aboriginal Rights: Defining the Just Society (Saskatoon: University of Saskatchewan Native Law Centre, 2007); Law Commission of Canada, ed, Indigenous Legal Traditions (Vancouver: UBC Press, 2007); Borrows, Canada's Indigenous Constitution, supra note 29; and John Borrows, Laws Indigenous Ethics (Toronto: University of Toronto Press, 2019). ${ }^{153}$ Delgamuukw, supra note 3 at para 117. The restriction on uses irreconcilable with the titleholders' attachment in the land, which Lamer CJ later referred to as an inherent limit, is one of the limitations on Aboriginal title that make it different from a fee simple estate. The other limitation is that it is inalienable other than by surrender to the Crown: ibid at para 113.
} 
This description of Aboriginal title which, as he later specified, includes natural resources on and under the land, including oil and natural gas, ${ }^{154}$ is a clear rejection of Lord Watson's characterization of Aboriginal title as "a personal and usufructuary right." 155

So what is the relevance of Indigenous law to Aboriginal title in Canada? Although not articulated in this way by the Chief Justice, my understanding is that its relevance is two-fold. As he did say, one function of Indigenous law is to provide additional evidence of exclusive occupation, which then gives rise to the generic interest described in the above quotation that entails proprietary rights against the outside world. ${ }^{156}$ But in addition to that, Indigenous law must apply internally to define Aboriginal title rights and interests among the titleholders themselves. The Aboriginal title described by Lamer $\mathrm{CJ}$ is a communal interest vested in the whole Indigenous nation, and yet his description provides no indication of how the land rights and interests are distributed, held, and regulated within the nation, other than to say that "[d]ecisions with respect to that land are also made by that community." 157 A second function of Indigenous law therefore must be to govern Indigenous landholding within Indigenous communities. This interpretation is consistent with Lamer CJ's holding that the Aboriginal title's "characteristics cannot be completely explained by reference either to the common law rules of real property or to the rules of property found in

\footnotetext{
${ }^{154}$ Ibid at paras 119-24.

${ }^{155}$ Lamer CJ remarked that what Lord Watson's description of Aboriginal title was meant "to capture is that aboriginal title is a sui generis interest in land", but his Lordship's "choice of terminology is not particularly helpful to explain the various dimensions of aboriginal title": ibid at para 112.

${ }^{156}$ See ibid at para 113, where Lamer CJ affirmed that Aboriginal title is proprietary in nature, as held in Canadian Pacific Ltd v Paul [1988] 2 SCR 654 at 677.

${ }^{157}$ Delgamuukw, supra note 3 at para 115. In Campbell v British Columbia [2000] 4 CNLR 1 (BCSC) [Campbell], Williamson $\mathrm{J}$ decided that this decision-making authority is governmental in nature, and so it could be a source of Indigenous law.
} 
aboriginal legal systems." 158 In short, the former rules apply externally and the latter apply internally. ${ }^{159}$ From a practical as well as a legal perspective, it cannot be otherwise: when the Crown supposedly asserted sovereignty over the Gitxsan and Wet'suwet'en territories, which the Supreme Court accepted as having happened in $1846,{ }^{160}$ the Crown exercised no authority there and no means would have been available for applying English law. So Gitxsan and Wet'suwet'en laws must have continued to apply to determine land rights within their territories, both because that would have been culturally appropriate and because no other law was available for that purpose. In the absence of valid legislative extinguishment of these laws prior to 1982 when they would have been recognized and affirmed by section 35 of the Constitution Act, 1982, ${ }^{161}$ they should continue to govern Gitxsan and Wet'suwet'en land rights internally today. ${ }^{162}$

In Delgamuukw, as in Calder, what allowed the Court to distinguish the St. Catherine's decision, on both the source and the content of Aboriginal title, was evidence of Indigenous law and occupation of land. In Delgamuиkw, this evidence was extensive - the trial took 374 days spread over three years, most of which involved presentation of evidence of Gitxsan and Wet'suwet'en laws and their relationship with the land. While not willing to make a decision on the merits, as explained above, the Supreme

\footnotetext{
${ }^{158}$ Delgamuukw, supra note 3 at para 112.

${ }^{159}$ Brian Slattery explained Aboriginal title in this way in an early article, "Understanding Aboriginal Rights” (1987) 66 Can Bar Rev 727 at 741-51.

${ }^{160}$ Delgamuиkw, supra note 3 at para 145. For critical commentary, see Kent McNeil, "Negotiated Sovereignty: Indian Treaties and the Acquisition of American and Canadian Territorial Rights in the Pacific Northwest", in Alexandra Harmon, ed, The Power of Promises: Rethinking Indian Treaties in the Pacific Northwest (Seattle: University of Washington Press, 2008), 35.

${ }^{161}$ Schedule B to the Canada Act 1982, (UK) 1982 c 11.

${ }^{162}$ In addition, because no legal system is frozen in time, these laws should be subject to modification by the exercise of Gitxsan and Wet'suwet'en governance authority, as was held by Williamson J in relation to the Nisga'a Nation in Campbell, supra note 157. For discussion, see Kent McNeil, "Judicial Approaches to Self-Government since Calder: Searching for Doctrinal Coherence", in Foster, Raven \& Webber, supra note 152 at 129 .
} 
Court did conclude from this evidence that Aboriginal title is sourced in Indigenous occupation and law, rather than in the Royal Proclamation of 1763, and is not limited to "a personal and usufructuary right". Then, in Tsilhqot'in Nation v British Columbia, ${ }^{163}$ the Court applied the doctrine laid down in Delgamuukw and, for the first time in Canadian judicial history, issued a declaration of Aboriginal title.

\section{(i) Tsilhqot'in Nation v British Columbia}

The trial in Tsilhqot'in Nation was also lengthy, consuming 339 court days. As in Delgamuukw, most of the testimony was on the Indigenous claimants' laws and relationship with the land, as detailed in Justice Vickers' detailed trial judgment. ${ }^{164}$ On the basis of this evidence, Chief Justice McLachlin, for a unanimous Supreme Court, was of the opinion that, as found by Vickers J, Aboriginal title to approximately half the claim area had been established. ${ }^{165}$ No reference to the St. Catherine's case was made in her judgment, revealing how far the Court had moved from that precedent. She relied instead on Delgamuиkw, where the

... Court confirmed the sui generis nature of the rights and obligations to which the Crown's relationship with Aboriginal peoples gives rise, and stated that what makes Aboriginal title unique is that it arises from possession before the assertion of British sovereignty, as distinguished from other estates such as fee simple that arise afterward. The dual perspectives of the common law and of the Aboriginal group bear equal weight in evaluating a claim for Aboriginal title. ${ }^{166}$

\footnotetext{
163 Tsilhqot'in Nation, supra note 4.

164 [2008] 1 CNLR 112 (BCSC).

165 Vickers $\mathrm{J}$ had nonetheless declined to issue a declaration of title because he thought the pleadings should have been amended to reflect the fact that the area where exclusive occupation had been proven was not the same as the claim area: ibid at paras 106-29. Before the Supreme Court, the Crown no longer argued that this should bar the claim, and the Court agreed: see Tsilhqot'in Nation, supra note 4 at paras 19-23.

166 Tsilhqot'in Nation, supra note 4 at para 14 (McLachlin CJ's emphasis).
} 
The Chief Justice thus confirmed and applied the ruling in Delgamuukw that Aboriginal title is based on exclusive occupation of land at the time the Crown asserted sovereignty, which was again taken to be 1846 in British Columbia. ${ }^{167}$ She did not, however, refer to Lamer CJ's opinion that "the relationship between common law and pre-existing systems of aboriginal law" is a second source of Aboriginal title. ${ }^{168}$ As revealed in the passage just quoted, her view of the role of Indigenous law was expressed in vague terms. ${ }^{169}$

Regarding the content of Aboriginal title, Chief Justice McLachlin confirmed what had been established in Delgamuukw, namely that

... Aboriginal title "encompasses the right to exclusive use and occupation of the land held pursuant to that title for a variety of purposes" ([Delgamuukw, ] para. 117), including non-traditional purposes, provided these uses can be reconciled with the communal and ongoing nature of the group's attachment to the land. Subject to this inherent limit, the title-holding group has the right to choose the uses to which the land is put and to enjoy its economic fruits. ${ }^{170}$

She elaborated as follows:

Aboriginal title confers ownership rights similar to those associated with fee simple, including: the right to decide how the land will be used; the right of enjoyment and occupancy of the land; the right to possess the land; the right to the economic

\footnotetext{
167 Ibid at paras 14, 25, 60 .

${ }^{168}$ Delgamuukw, supra note 3 at para 114.

${ }^{169}$ See also Marshall/Bernard, supra note 138, per McLachlin CJ. Compare LeBel J's concurring judgment.

${ }^{170}$ Tsilhqot'in Nation, supra note 4 at para 68. However, McLachlin CJ modified the inherent limit somewhat, making it a forward-looking principle of sustainable development that appears to be less restricted by traditional uses: ibid at para 74. Moreover, she added that it also limits government authority to infringe, so "incursions on Aboriginal title cannot be justified if they would substantially deprive future generations of the benefit of the land": ibid at para 86.
} 
benefits of the land; and the right to pro-actively use and manage the land. ${ }^{171}$

As Aboriginal title is an entire beneficial interest, the underlying title the Crown acquired with sovereignty has no beneficial content whatsoever. ${ }^{172}$

Summing up the modern Canadian case law, in light of extensive evidence of Indigenous land use and law, Supreme Court decisions starting with Calder in 1973 have rejected Lord Watson's opinion that the Royal Proclamation of 1763 is the source Aboriginal title. Instead, it is based on the common law rule that ownership can be derived from possession and the doctrine that pre-existing land rights continue after Crown acquisition of sovereignty. As the content of Aboriginal title depends largely on its source, the Court has also rejected Lord Watson's characterization of the title as "a personal and usufructuary right" and decided that it amounts to the entire beneficial interest in the land. The existence of Aboriginal title is thus a matter of fact that depends on evidence of exclusive occupation, which can be established by proof of physical presence on and use of the land and by Indigenous law.

\section{Conclusion}

Our examination of the modern case law has revealed just how far the highest courts in Australia and Canada have moved from the early precedents of Cooper v Stuart and St. Catherine's on the existence, sources, and content of Indigenous land rights. While this might be thought of as amounting to substantial modification of the law, ${ }^{173}$ the analysis in this

\footnotetext{
${ }^{171}$ Ibid at para 73.

172 Ibid at para 70. For discussion, see Kent McNeil, “The Source, Nature, and Content of the Crown's Underlying Title to Aboriginal Title Lands" (2018) 96 Can Bar Rev 275.

173 See the works cited supra note 8.
} 
article has revealed that those early pronouncements of the Privy Council were made in factual vacuums, with erroneous assumptions about Indigenous societies and their relationships with the land being made in the complete absence of any evidence in relation to those matters.

By way of contrast, in the modern cases in both countries extensive evidence of the cultures and laws of the Indigenous peoples concerned and of their relationships with the land has been presented. This evidence has permitted the judges to apply elements of the common law going back well before those Privy Council decisions from the 1880s, specifically the principle that possession of land is proof of ownership and the doctrine that pre-existing rights continue when the Crown extends its sovereignty over new territory. These common law doctrines have provided the courts with two potential sources of Indigenous land rights, namely occupation of land and Indigenous law. Depending on which source is applied, the content of the land rights is then determined by common law principles in relation to possession, Indigenous laws, or a combination of the two. In Australia, the High Court has adopted the Indigenous law approach, ${ }^{174}$ whereas in Canada the Supreme Court has applied the common law to determine the content of Aboriginal title externally, leaving space for the application of Indigenous law internally.

\footnotetext{
174 This approach was made statutory through a questionable interpretation of Justice Brennan's judgment in Mabo No 2 by s 223(1) of the Native Title Act 1993: see supra notes 128, 145. In Ward and Yorta Yorta, supra note 127, that subsection was rigidly interpreted and applied to limit the scope of native title rights: see Richard Bartlett, "Humpies not Houses or the Denial of Native Title: A Comparative Assessment of Australia's Museum Mentality" (2003) 10 Aust Prop LJ 1; Tehan, supra note 145; Young, The Trouble with Tradition, supra note 58, especially 291-312. More recently, in Akiba, supra note 127, the High Court took a somewhat more generous approach to the content of native title rights: see Sean Brennan, "The Significance of the Akiba Torres Strait Regional Sea Claim Case", in Sean Brennan et al, eds, Native Title from Mabo to Akiba: A Vehicle for Change and Empowerment? (Sydney: Federation Press, 2015), 29; Patrick McCabe, "Pilki and Birriliburu: Commercial Native Title Rights after Akiba" (2015) 19:2 AILR 64; Simon Young, "The Increments of Justice: Exploring the Outer Reach of Akiba's Edge towards Native Title 'Ownership"' (2019) 42 UNSWLJ 825.
} 